\title{
Decision Document for the Storm Water Outfalls/Industrial Wastewater Treatment Plant, Pesticide Rinse Area, Old Fire Fighting Training Pit, Illicit PCB Dump Site, and the Battery Acid Pit Fort Lewis, Washington
}

\author{
K. J. Cantrell \\ T. L. Liikala \\ D.L. Strenge \\ R.Y. Taira
}

December 2000

Prepared for

the U.S. Army Forces Command

Fort Lewis, Washington

Pacific Northwest National Laboratory

Richland, Washington 99352 


\section{LEGAL NOTICE}

This report was prepared by Battelle Memorial Institute (Battelle) as an account of sponsored research activities. Neither Client nor Battelle nor any person acting on behalf of either:

\section{MAKES ANY WARRANTY OR REPRESENTATION, EXPRES OR}

IMPLIED, with respect to the accuracy, completeness, or usefulness of the information contain in this report, or that the use of any information, apparatus, process, or composition disclosed in this report may not infringe privately owned rights; or

Assumes any liabilities with respect to the use of, or for damages resulting from the use of, any information, apparatus, process, or composition disclosed in this report.

Reference herein to any specific commercial product, process, or service by trade name, trademark, manufacturer, or otherwise, does not necessarily constitute or imply its endorsement, recommendation, or favoring by Battelle. The views and opinions of authors expressed herein do not necessarily state or reflect those of Battelle. 


\section{Summary}

Pacific Northwest National Laboratory (PNNL) conducted independent site evaluations for four sites at Fort Lewis, Washington to determine their suitability for closure on behalf of the installation. These sites were recommended for "No Further Action" by previous investigators and included the Storm Water Outfalls/Industrial Waste Water Treatment Plant (IWTP), the Pesticide Rinse Area, the Old Fire Fighting Training Pit, and the Illicit PCB (polychlorinated biphenyls) Dump Site. The Battery Acid Pit, originally scheduled to have an Engineering Evaluation/Cost Analysis (EE/CA) performed, was also considered here for no further action following consultation with Fort Lewis and the U.S. Environmental Protection Agency (EPA).

Generally, a five-step approach was used in this work: 1) an initial data review was performed including the Installation Restoration Action Plan and supporting documentation, 2) a site visit was conducted to assess site-specific conditions including previous response actions, 3) a workplan was developed for any additional characterization work required (limited sampling), 4) the sites were evaluated to determine their suitability for closure based on available data, and 5) the results were presented to Fort Lewis and EPA for concurrence and are reported in this decision document. A removal action and limited field investigation were performed at the Illicit PCB Dump Site, along with installation of a cap before this effort. Following data review, a screening risk assessment was performed on the Pesticide Rinse Area, confirmational soil samples were collected at the Old Fire Fighting Training Pit, and a health impact assessment was conducted on the Battery Acid Pit.

"No Further Action" is required for future response under the Comprehensive Environmental Response, Compensation, and Liability Act (CERCLA) for the Storm Water Outfalls/IWTP, the Pesticide Rinse Area, and the Old Fire Fighting Training Pit. For the Storm Water Outfalls/IWTP, several samples contained concentrations of benzo(a)pyrene above the EPA Region 9 Preliminary Remediation Goal (PRG) for industrial soils. However, the results were below applicable background concentrations. The outfalls are subject to Clean Water Act requirements and are covered by a National Pollutant Discharge Elimination System (NPDES) permit.

At the Pesticide Rinse Area, one of 15 soil samples exceeded the industrial screening criteria for chlordane applicable at the time of data analysis. The screening risk assessment was conducted to evaluate the significance of this contamination. Modeling results indicate that the chlordane will never reach the groundwater due to a combination of adsorption and degradation. In fact, natural degradation will reduce the chlordane inventory to insignificant levels within 80 years. A comparison with more recent EPA Region 9 PRGs indicates that none of the pesticides exceed the criteria for industrial soils. This site should, however, be included in a future Institutional 
Control Plan for Fort Lewis. If the land use changes to residential, EPA should be notified and the risk assessment should be updated. The Pesticide Rinse Area should also be included in the Fort Lewis Logistics Center 5-year reviews because contamination is being left in place. These recommendations should be formally addressed in an Explanation of Significant Difference (ESD) to the Logistics Center Record of Decision (ROD).

Recent results from the Old Fire Fighting Training Pit showed detectable levels of total petroleum hydrocarbons (TPH) in two soil samples. However, the concentrations are well below the Model Toxics Control Act (MTCA) interim cleanup level of $200 \mathrm{mg} / \mathrm{kg}$. No volatile organic compounds (VOCs) were found above their respective method detection limits (MDLs) during the confirmatory soil sampling.

As a result of the removal action, the installation and current condition of the cap, and previous groundwater results at the Illicit PCB Dump Site, no threat to public health or the environment is expected. Recommendations to 1) abandon wells drilled at this site during the 1980 s to prevent them from being a potential route for contaminant migration and 2) install a 6-ft-high chain link fence to prevent any disturbance of the site, have been completed. The cap was also debrushed. Additional groundwater monitoring over a two-year period is underway. Two sampling events have been completed (March and July 1999). Two more rounds should be completed; one round in the fall and one in the winter. The samples should be analyzed for PCBs and trichlorobenzene. If no contamination is detected, it is recommended that the site be closed. Further investigation may be warranted if contamination is detected. In either case, this site should be included as part of the future Institutional Control Plan for Fort Lewis and the Logistics Center 5-year reviews because contamination is being left in place. These recommendations should also be addressed in the ESD to the Logistics Center ROD.

Exposure to residual lead in the Battery Acid Pit was assessed for a worker assumed to be working directly at the site and an individual located $100 \mathrm{~m}$ from the site. For the individual working directly at the site, the total potential median blood lead level concentration was calculated to be $1.1 \mu \mathrm{g} \mathrm{Pb} / \mathrm{dL}$ blood. At the 95th percentile, the blood lead level concentration was determined to be $2.0 \mu \mathrm{g} \mathrm{Pb} / \mathrm{dL}$ blood. These results can be compared to the EPA guideline of $10 \mu \mathrm{g} \mathrm{Pb} / \mathrm{dL}$ blood. For the individual located $100 \mathrm{~m}$ from the site, the blood lead level was calculated to be $1.3 \mathrm{E}-15 \mu \mathrm{g} \mathrm{Pb} / \mathrm{dL}$ blood. These results indicate that even with relatively conservative assumptions used in the health impact assessment, the calculated blood lead level was more than a factor of five below the EPA guideline. Therefore, it is recommended that no further action be taken at the Battery Acid Pit, other than paving the site with asphalt to remove any potential exposure altogether, which has been completed. EPA should be notified if the land use changes to residential and the health impact assessment should be updated. The Battery Acid Pit should also be included in the Fort Lewis Logistics Center 5-year reviews because 
contamination is being left in place. Additionally, these recommendations should be addressed in the ESD to the Logistics Center ROD. 


\section{Acronyms and Abbreviations}

$\begin{array}{ll}\mathrm{B}_{\mathrm{a}} & \text { blood lead level from air inhalation intake }(\mu \mathrm{g} \mathrm{Pb} / \mathrm{dL} \text { blood }) \\ \mathrm{B}_{\mathrm{d}} & \text { blood lead level from soil dermal contact intake }(\mu \mathrm{g} \mathrm{Pb} / \mathrm{dL} \text { blood }) \\ \mathrm{B}_{\mathrm{s}} & \text { blood lead level from soil ingestion intake }(\mu \mathrm{g} \mathrm{Pb} / \mathrm{dL} \text { blood }) \\ \mathrm{C}_{\mathrm{a}} & \text { average concentration of lead in air }\left(\mu \mathrm{g} / \mathrm{m}^{3}\right) \\ \mathrm{C}_{\mathrm{ds}} & \begin{array}{l}\text { air concentration for exposure to airborne material above contaminated soil } \\ \left(\mu \mathrm{g} / \mathrm{m}^{3}\right)\end{array}\end{array}$

CERCLA Comprehensive Environmental Response, Compensation, and Liability Act

cfs $\quad$ cubic feet per second

$\mathrm{C}_{\mathrm{s}} \quad$ average soil concentration over the exposure period $(\mu \mathrm{g} / \mathrm{kg})$

DoD Department of Defense

Ecology $\quad$ State of Washington Department of Ecology

EE/CA Engineering Evaluation/Cost Analysis

EPA (U.S.) Environmental Protection Agency

ESD Explanation of Significant Difference

$\mathrm{F}_{\mathrm{ds}} \quad$ fraction of days in a year that exposure occurs

FFA Federal Facilities Agreement

FORSCOM (U.S. Army) Forces Command

$\mathrm{F}(\mathrm{x}) \quad$ function depending on $\mathrm{U}_{\mathrm{m}} / \mathrm{U}_{\mathrm{t}}$ derived using Cowherd et al. (1984) (unitless)

$\mathrm{I}_{\mathrm{d}} \quad$ daily contact rate with soil by a worker $(\mathrm{kg} / \mathrm{d})$

$\mathrm{I}_{\mathrm{S}} \quad$ daily intake rate of soil by a worker $(\mathrm{kg} / \mathrm{d})$ 


\begin{tabular}{|c|c|}
\hline IWTP & Industrial Wastewater Treatment Plant \\
\hline MDLs & method detection limits \\
\hline MEPAS & Multimedia Environmental Pollutant Assessment System \\
\hline$\mu \mathrm{g} / \mathrm{L}$ & micrograms per Liter \\
\hline $\mathrm{mg} / \mathrm{d}$ & milligrams per day \\
\hline $\mathrm{mg} / \mathrm{kg}$ & milligrams per kilogram \\
\hline $\mathrm{mg} / \mathrm{L}$ & milligrams per Liter \\
\hline $\mathrm{mL} / \mathrm{g}$ & milliliters per gram \\
\hline $\mathrm{M}_{\mathrm{o}}$ & initial mass at time $=0(\mathrm{~g})$ \\
\hline MTCA & Model Toxics Control Act \\
\hline $\mathrm{M}_{\mathrm{t}}$ & mass remaining at time $\mathrm{t}(\mathrm{g})$ \\
\hline NPDES & National Pollutant Discharge Elimination System \\
\hline PA & preliminary assessment \\
\hline PAHs & polycyclic aromatic hydrocarbons \\
\hline PCBs & polychlorinated biphenyls \\
\hline $\mathrm{PEF}$ & particle emission factor $\left(\mathrm{m}^{3} / \mathrm{kg}\right)$ \\
\hline PID & photoionization detector \\
\hline PNNL & Pacific Northwest National Laboratory \\
\hline PPMv & parts per million by volume \\
\hline PRG & preliminary remediation goal \\
\hline QA & quality assurance \\
\hline
\end{tabular}




\begin{tabular}{|c|c|}
\hline $\mathrm{Q} / \mathrm{C}$ & inverse of mean concentration at center of a square source $\left(\mathrm{g} / \mathrm{m}^{2}-\mathrm{s}\right.$ per $\left.\mathrm{kg} / \mathrm{m}^{3}\right)$ \\
\hline RCRA & Resource Conservation and Recovery Act \\
\hline ROD & Record of Decision \\
\hline SEATAC & Seattle-Tacoma International Airport \\
\hline SVOCs & semivolatile organic compounds \\
\hline $\mathrm{t}$ & time $(y r)$ \\
\hline TCE & trichloroethylene \\
\hline TCLP & Toxicity Characteristic Leaching Procedure \\
\hline TPH & total petroleum hydrocarbons \\
\hline $\mathrm{U}_{\mathrm{m}}$ & mean annual windspeed $(\mathrm{m} / \mathrm{s})$ \\
\hline USACE & U.S. Army Corps of Engineers \\
\hline $\mathrm{U}_{\mathrm{t}}$ & equivalent threshold value of windspeed at 7 meters $(\mathrm{m} / \mathrm{s})$ \\
\hline $\mathrm{V}$ & fraction of land covered by vegetation (unitless) \\
\hline VOCs & volatile organic compounds \\
\hline$\lambda$ & decay rate coefficient (1/yr) \\
\hline
\end{tabular}




\section{Acknowledgments}

The authors would like to thank J. G. Bush and J. S. Fruchter for their technical guidance throughout this project. Thanks to B. N. Bjornstad and J. W. Lindberg for their field work. Thanks also to D. C. Lanigan for providing graphics, and J. R. Draper for editorial review. 


\section{Contents}

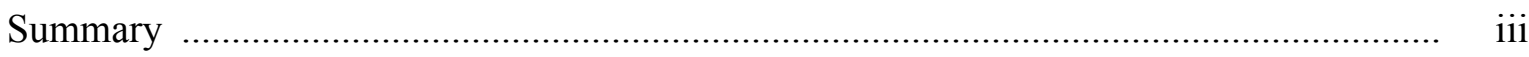

Acronyms and Abbreviations ..................................................................................... vii

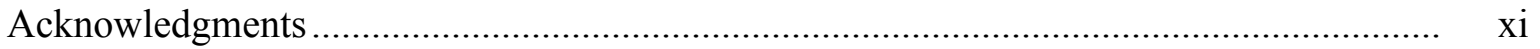

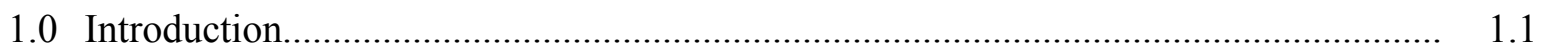

2.0 Storm Water Outfalls/Industrial Wastewater Treatment Plant ................................. 2.1

2.1 Summary of Previous Analytical Results .................................................. 2.1

2.2 Conclusions and Recommended Action ................................................... 2.3

3.0 Pesticide Rinse Area ...................................................................................... 3.1

3.1 Summary of Previous Analytical Results ...................................................... 3.1

3.2 Screening Risk Assessment ..................................................................... 3.3

3.2.1 Computer Modeling ….................................................................... 3.3

3.2.2 Natural Degradation ....................................................................... 3.5

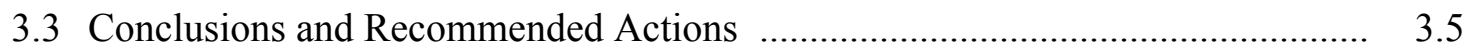

4.0 Old Fire Fighting Training Pit f.................................................................... 4.1

4.1 Summary of Previous Analytical Results ................................................... 4.1

4.2 Confirmatory Soil Sampling Results …................................................... 4.3

4.3 Conclusions and Recommended Action ................................................... 4.4

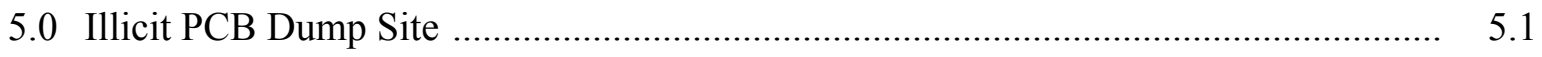

5.1 Summary of Previous Analytical Results ................................................ 5.1

5.2 Conclusions and Recommended Actions ................................................... 5.4 
6.1 Summary of Previous Analytical Results

6.2 Health Impact Assessment for Exposure to Lead .......................................... 6.4

6.2.1 Inhalation of Contaminant from Soil Suspension ..................................... 6.5

6.2.2 Ingestion of Contaminated Soil .......................................................... 6.6

6.2.3 Dermal Contact with Contaminated Soil ............................................... 6.7

6.2.4 Summary of Blood Lead Levels ............................................................. 6.7

6.2.5 Exposure to Lead at 100 Meters .............................................................. 6.8

6.3 Conclusions and Recommended Actions....................................................... 6.9

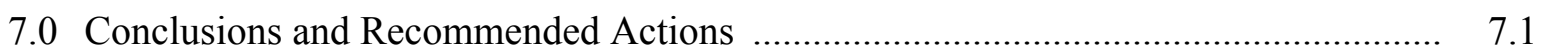

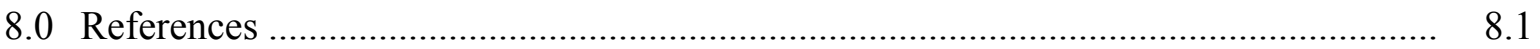




\section{Figures}

1.1 Generalized Location Map for Fort Lewis................................ 1.2

2.1 Location Map for the Storm Water Outfalls/IWTP and Sediment Sampling Sites ....... 2.2

3.1 Location Map for the Pesticide Rinse Area ............................................................. 3.2

3.2 Ratio of Chlordane Mass Remaining to Initial Chlordane Mass as a Function of Time 3.6

4.1 Location Map for the Old Fire Fighting Training Pit and Confirmatory Soil Sampling Locations (From October 6, 1998) ...................................................................... 4.2

5.1 Location Map for the Illicit PCB Dump Site .................................................... 5.2

6.1 Location Map for the Battery Acid Pit................................................................ 6.2

\section{Tables}

3.1 Input Parameter Values Used in MEPAS ............................................................ 3.4

4.1 Old Fire Fighting Training Pit Confirmatory Soil Sampling Results ........................ 4.3

6.1 Lead and pH Results for Battery Acid Pit Soil Samples ..................................... 6.4

6.2 Blood Lead Levels at Various Median Percentiles................................................ 6.8

6.3 Percent Sand, Soil Particle Suspension Rate, and Air Concentration ....................... $\quad 6.9$ 


\subsection{Introduction}

The Defense Environmental Restoration Program is continually faced with the challenge of allocating limited Congressionally authorized funds to achieve its environmental restoration objectives. The amount of work identified by individual Department of Defense (DoD) installations greatly exceeds the level of funding allocated in a single year. Therefore, DoD must efficiently and effectively assess, rank, and remediate their hazardous waste sites accordingly to protect human health and the environment.

Fort Lewis is a U.S. Army Forces Command (FORSCOM) Installation. Preliminary assessments (PAs) conducted for four sites at the installation, the Storm Water Outfalls/Industrial Wastewater Treatment Plant (IWTP), the Pesticide Rinse Area, the Old Fire Fighting Training Pit, and the Illicit PCB (polychlorinated biphenyls) Dump Site (Figure 1.1), have resulted in "No Further Action" recommendations for future response. A removal action and limited field investigation were performed at the Illicit PCB Dump Site subsequent to the PA.

In addition to the sites mentioned above, a fifth site, the Battery Acid Pit, is also included in this document. The Battery Acid Pit is regulated as part of the Logistics Center, which was placed on the National Priorities List in December 1989 as a result of groundwater contamination beneath the center. A Federal Facilities Agreement (FFA) between the U.S. Environmental Protection Agency (EPA), the State of Washington Department of Ecology (Ecology), and the Army was formalized in January 1990. This FFA established a procedural framework and schedule for developing, implementing, and monitoring appropriate response actions at the Logistics Center.

Fort Lewis requested Pacific Northwest National Laboratory (PNNL) to perform independent site evaluations for the Storm Water Outfalls/IWTP, the Pesticide Rinse Area, the Old Fire Fighting Training Pit, and the Illicit PCB Dump Site to determine their suitability for closure. PNNL reviewed pertinent documentation provided by Fort Lewis and performed a site visit. PNNL, and subsequently Fort Lewis and EPA, concur with the "No Further Action" recommendation under the Comprehensive Environmental Response, Compensation, and Liability Act (CERCLA) for the Storm Water Outfalls/IWTP. Following consultation with Fort Lewis and EPA, a screening risk assessment was performed to evaluate the significance of chlordane contamination in soil at the Pesticide Rinse Area. As a result of data gaps from the previous investigations, PNNL proposed that limited confirmatory soil sampling and analysis be conducted at the Old Fire Fighting Training Pit to assess the potential for volatile organic compound (VOC) contamination. Well abandonment, institutional controls, and limited sampling were negotiated with Fort Lewis and EPA for the Illicit PCB Dump Site. 


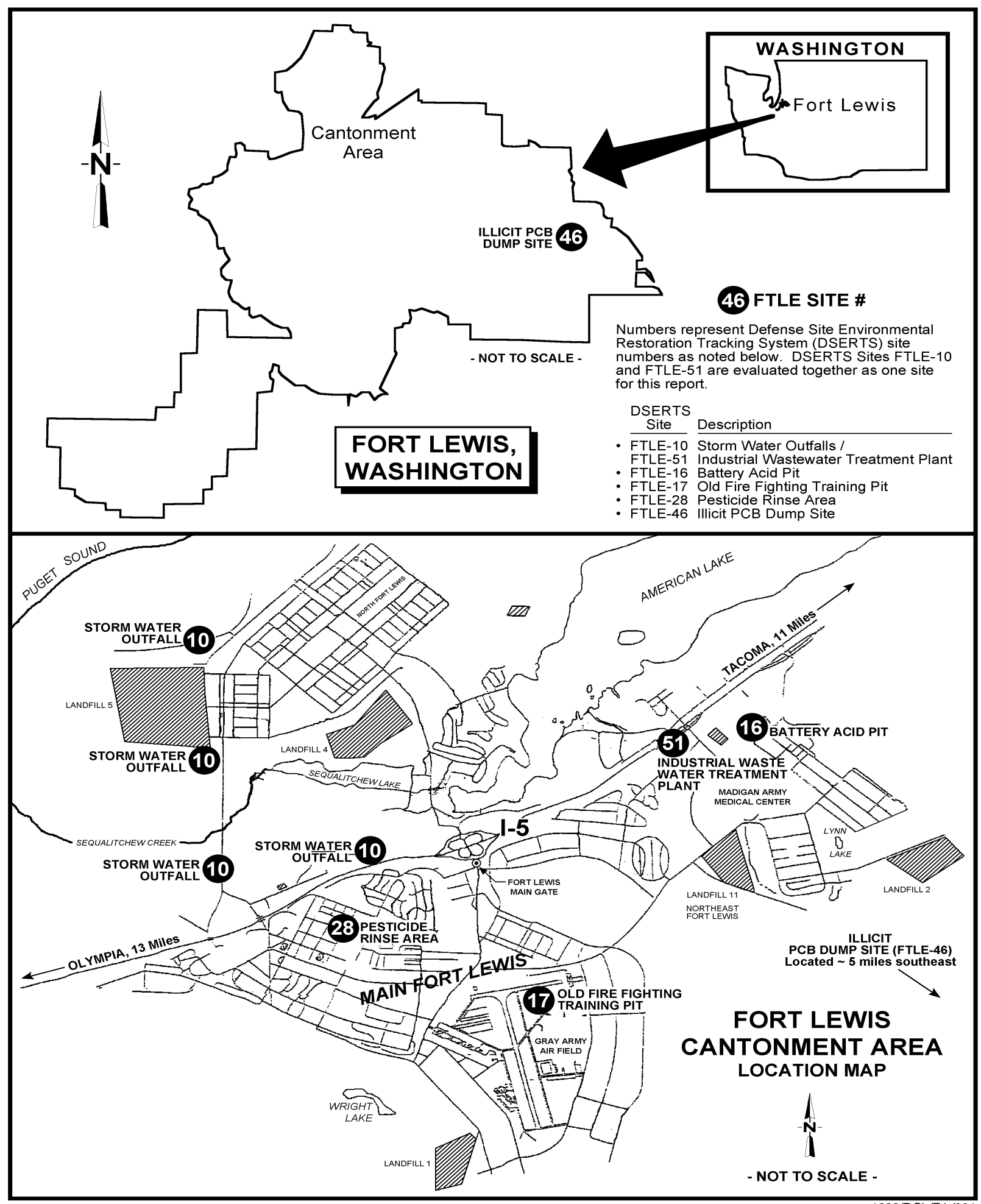

Figure 1.1. Generalized Location Map for Fort Lewis 
Fort Lewis also requested PNNL to perform an Engineering Evaluation/Cost Analysis (EE/CA) for the Battery Acid Pit. After a review of supporting documentation provided by Fort Lewis and a site visit to collect additional information, PNNL completed a draft EE/CA. This EE/CA contained various remedial alternatives designed to meet regulatory requirements. The various remedial options were presented to Fort Lewis and EPA. Subsequently, it was agreed that a no further action scenario was likely to be the most appropriate course of action for the Battery Acid Pit. To support this, it was determined that a health impact assessment for exposure to lead would be conducted.

This decision document is organized as follows. Site descriptions, background information, a summary previous analytical results, conclusions and recommended action(s) are given for the Storm Water Outfalls/IWTP, the Pesticide Rinse Area, the Old Fire Fighting Training Pit, the Illicit PCB Dump Site, and the Battery Acid Pit in Sections 2.0 through 6.0, respectively. Conclusions and recommended actions are provided in Section 7.0. References cited in the text are listed in Section 8.0. 


\subsection{Storm Water Outfalls/Industrial Wastewater Treatment Plant}

Storm water runoff is discharged to five locations from various portions of Fort Lewis (Figure 2.1). Runoff from North Fort Lewis is discharged at two outfalls, Solo Point I and Solo Point II. These outfalls discharge into a drainage channel that empties into Puget Sound. Storm water runoff from the main cantonment area at Fort Lewis is conveyed to the Flora Road and DuPont outfalls and then discharged into tributaries to the same unlined channel as the Solo Point outfalls. Dissolved air flotation units remove oil and grease from the storm water at these outfalls before it is discharged into the unlined channels. Storm water from the Logistics Center is conveyed to the Fort Lewis IWTP. When flow to the plant exceeds the two-year runoff event of $6 \mathrm{cfs}$, the excess water is discharged into Murray Creek, which empties into American Lake. Water entering the IWTP at flows less than $6 \mathrm{cfs}$ is treated and then discharged into an evaporation/percolation pond, which has no surface outlet.

\subsection{Summary of Previous Analytical Results}

The first investigations of the storm water outfalls were conducted in 1986. Initially, an effluent sample was collected from the Murray Creek outfall during a study of the Logistics Center and analyzed for VOCs. Only trichloroethylene (TCE) was detected $(9 \mu \mathrm{g} / \mathrm{L})$. Sediment samples were collected from directly in front of each of the five outfalls in October 1986. The samples were analyzed for VOCs, semivolatile organic compounds (SVOCs), pesticides/PCBs, metals, and cyanide. Nine metals were detected, but only arsenic exceeded the risk-based threshold (Tetra Tech 1993). Arsenic levels at all five outfalls exceeded the risk-based threshold; however, the observed arsenic concentrations are within the range of reported background levels in freshwater sediments (Tetra Tech 1993). The analytical results exhibited significant quality assurance (QA) problems including matrix interference caused by oil in the samples (U.S. Army 1990).

As a result of the QA problems, a limited field investigation was conducted in 1993 by Woodward-Clyde to determine if the storm water outfalls have contributed metals, polycyclic aromatic hydrocarbons (PAHs), and petroleum hydrocarbons to sediments in the receiving water bodies. For the purposes of this study, the unlined Solo Point drainage ditch was considered to be the receiving water body for Solo Point I and Solo Point II. Hamer and MacKay Marshes are the receiving water bodies for the Flora Road and DuPont outfalls, respectively. Murray Creek is the receiving water body for the IWTP outfall.

Surface sediment samples were collected upstream and downstream from the receiving water bodies of the Solo Point I, Solo Point II, and Murray Creek outfalls (Figure 2.1). Only 


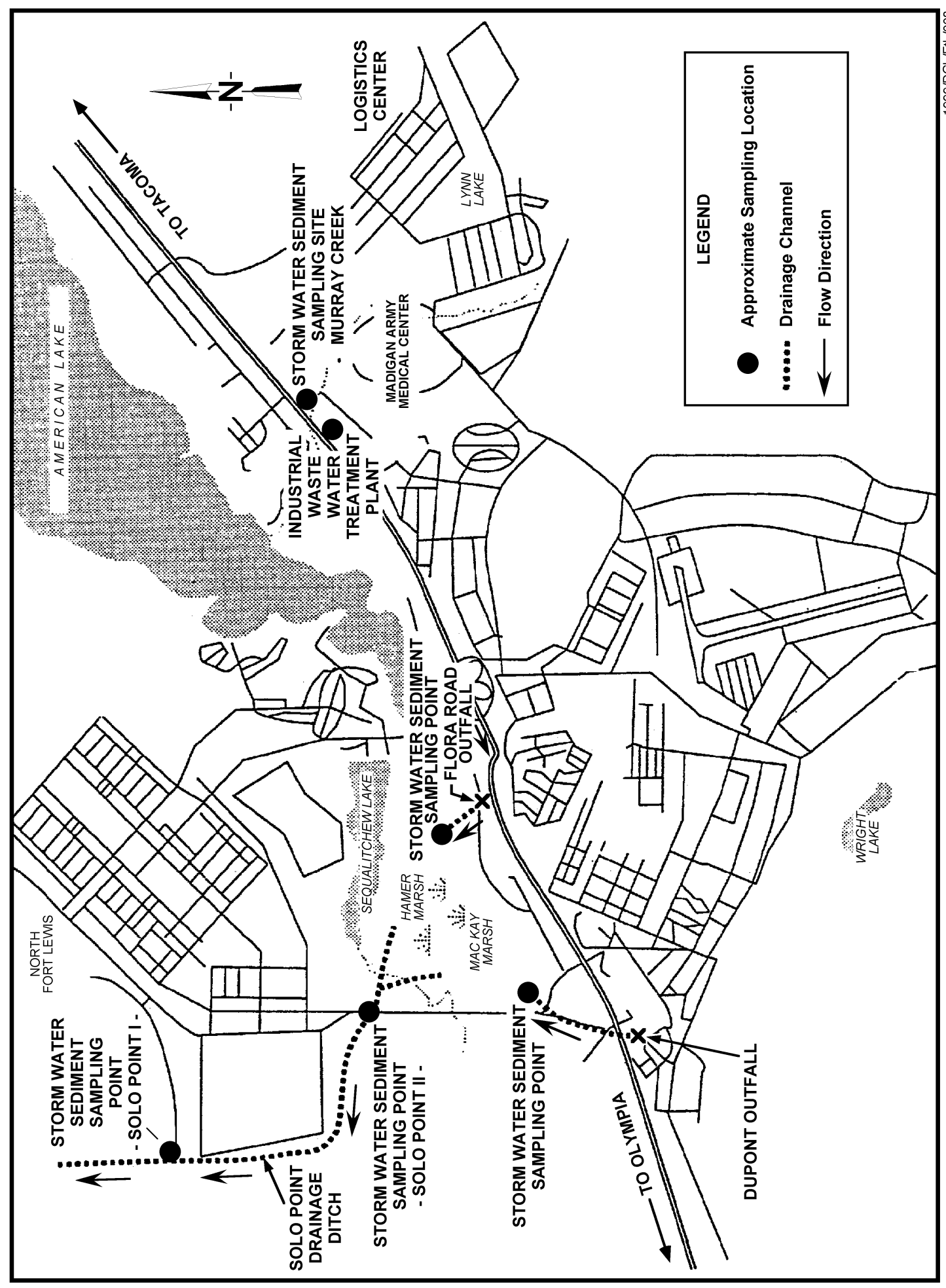

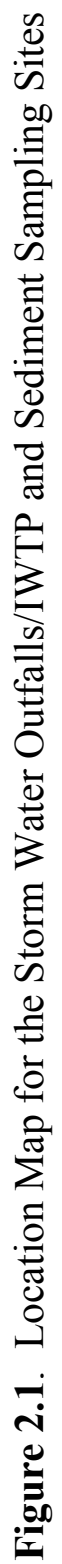


downstream sediment samples were collected at the Flora Road and DuPont outfalls because runoff from numerous catch basins is combined at these outfalls. Samples were analyzed for metals (EPA Methods 6000-7000), PAHs (EPA Method 8310), and total petroleum hydrocarbons (TPH) (EPA Method 8015).

Analytical results indicate that several PAHs and arsenic exceeded EPA Region 3 Risk-Based Screening Criteria for residential soils (Woodward-Clyde 1994). However, the PAH concentrations were lower than those in residential catch basin sediments in the Puget Sound region. Therefore, the PAH concentrations found in the sediments were attributed to urban runoff rather than releases from hazardous waste sites or industrial activities. Likewise, the arsenic concentrations in the outfall sediments were lower than non-industrial sediments in Lake Washington, indicating that these concentrations were also attributable to urban runoff rather than releases from hazardous waste sites or industrial activities. TPH concentrations found in the sediment samples were similar to those found in Puget Sound street dirt (Hong West \& Associates 1993) and lower than those typically detected in residential catch basins (Serdar 1993). As a result of these findings, no further action was recommended for the Storm Water Outfalls/IWTP. A comparison with more recent EPA Region 9 Preliminary Remediation Goals (PRGs) for industrial soils (EPA 1998) indicates that only benzo(a)pyrene exceeds these standards.

\subsection{Conclusions and Recommended Action}

Site characterization and analytical results from the Storm Water Outfalls/IWTP were reviewed and a site visit performed. Several outfall samples were found to contain concentrations of PAHs and arsenic that exceeded EPA Region 3 Risk-Based Screening Criteria for residential soils; however, these results were below applicable background concentrations. As a result of these findings, no further action was recommended for this site. PNNL, along with Fort Lewis and EPA, concur with this recommendation under CERCLA, as comparing these results with more recent EPA Region 9 PRGs for industrial soils indicates that the only compound to exceed these standards is benzo(a)pyrene. The outfalls are subject to requirements under the Clean Water Act and are covered by a National Pollutant Discharge Elimination System (NPDES) permit. 


\subsection{Pesticide Rinse Area}

The Pesticide Rinse Area is an unbermed, $34-\mathrm{ft}$ by $34-\mathrm{ft}$, concrete pad outside a pesticide storage area. It is located between North $3^{\text {rd }}$ and North $5^{\text {th }}$ Streets on Crary Avenue on the south side of Building No. 2054 (Figure 3.1). The pad was used for at least 24 years as a rinse site for applicator equipment and empty chemical containers (Tetra Tech 1993). The pad is dissected by many cracks, some of which extend to the base of the concrete.

\subsection{Summary of Previous Analytical Results}

In 1986, the U.S. Army Corps of Engineers (USACE) collected samples of surface soil at four locations along the south side of Building No. 2054. The four samples were combined to form a single composite sample that was analyzed for organochlorine pesticides and PCBs (EPA Method 8080). One pesticide, 4,4-DDE, was detected in the composite sample at $0.005 \mathrm{mg} / \mathrm{kg}$ (U.S. Army 1990). USACE regarded these results as inconclusive for several reasons. First, only two of the four subsamples used to form the composite sample were collected adjacent to the rinse area. Consequently, the compositing process may have diluted higher pesticide concentrations in the soil immediately adjacent to the pad. Second, soils underlying the cracks in the pad were not sampled. Third, subsurface soils were not sampled. Fourth, the chemical analysis was limited to organochlorine pesticides and PCBs. The samples were not analyzed for 2,4-D and 2,4,5-T, which are known to have been handled at this site. The analyses also did not include dioxins that can be present at trace levels in 2,4,5-T. And finally, groundwater was not sampled.

A limited field investigation of the Pesticide Rinse Area was conducted in 1993-94 to address the uncertainties identified by the USACE. The primary objective was to determine if potentially significant concentrations of 2,4-D, 2,4,5-T, organochlorine pesticides, PCBs, and dioxins and furans were present in soils and groundwater at the Pesticide Rinse Area. Analyses for potential soil and groundwater contaminants were chosen based on records provided by Fort Lewis.

Five exploratory borings were drilled in November 1993 and April 1994 (Figure 3.1). Soil samples were collected from three borings in the unpaved area immediately south of the pad and from two borings through cracks in the pad. Sampling intervals for all borings were $0.5,2$, and $10 \mathrm{ft}$. One sample was also collected in one boring from $50 \mathrm{ft}$. From the surface to a depth of approximately $66 \mathrm{ft}$, the soil is composed of silty, sandy gravel and cobbles. One monitoring well was installed $15 \mathrm{ft}$ south of the pad in the path of surface water runoff from the pad. Groundwater was encountered at a depth of $59 \mathrm{ft}$. 


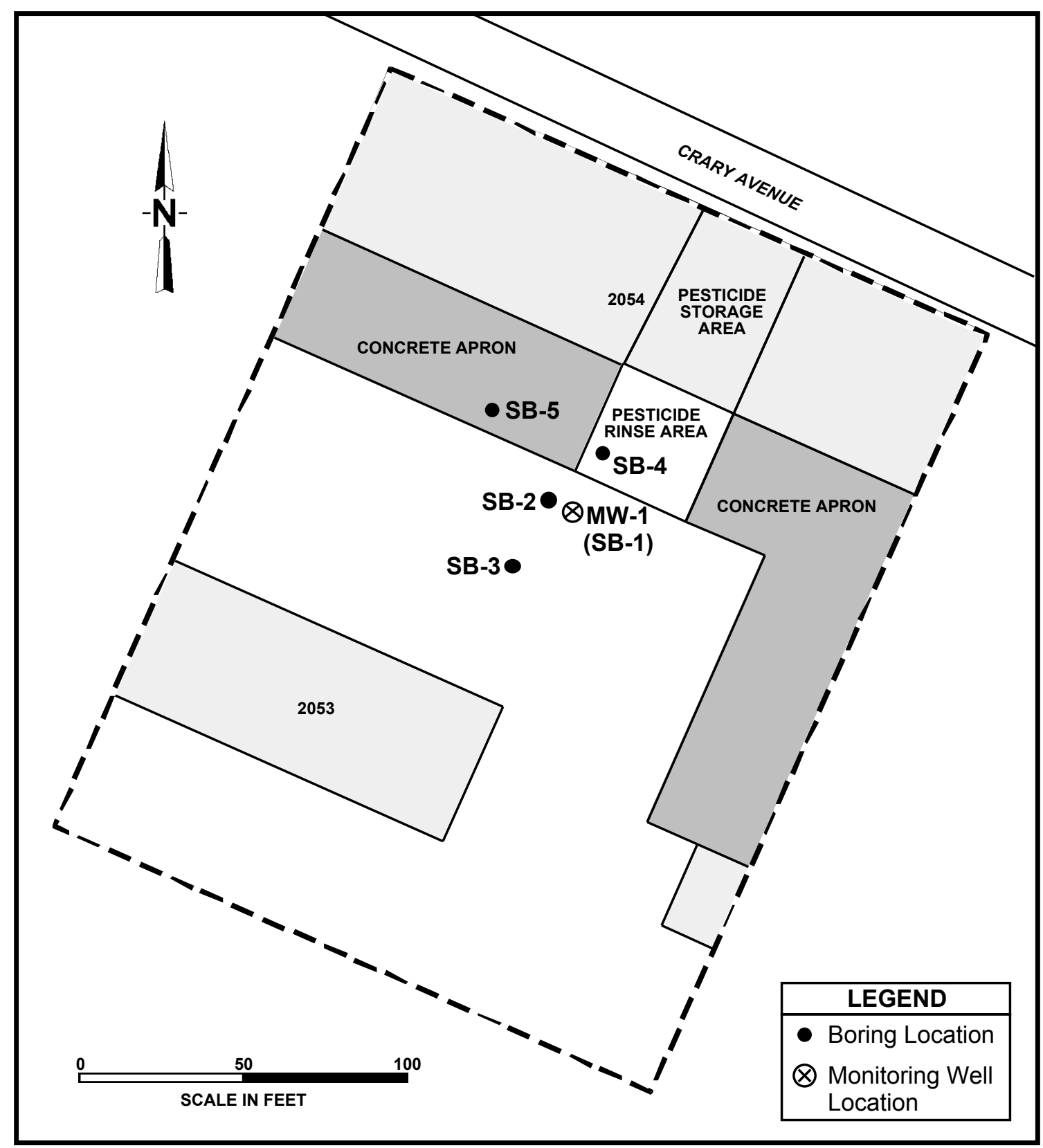

1999/DCL/FtL/005

Figure 3.1. Location Map for the Pesticide Rinse Area 
Fifteen of the soil samples and one groundwater sample were analyzed for chlorinated herbicides, PCBs, pesticides, and total organic carbon. Chlordane was the only analyte detected that exceeded industrial screening criteria for soils applicable at the time of analysis. It was detected in one 2- $\mathrm{ft}$ sample beneath the concrete pad at a concentration of $10 \mathrm{mg} / \mathrm{kg}$ (WoodwardClyde 1994). The industrial screening criteria for chlordane was $2.2 \mathrm{mg} / \mathrm{kg}$. Chlordane, dieldrin, and heptachlor exceeded residential screening criteria. No pesticides or PCBs were detected in the groundwater sample. Following discussions with Fort Lewis and EPA, a screening risk assessment was conducted to evaluate the significance of the chlordane contamination exceeding industrial screening criteria. Details of this assessment are presented below. Since the time when the assessment was completed, a comparison with more recent standards was made which shows that the chlordane concentrations are below the EPA Region 9 PRG for industrial soils (12 $\mathrm{mg} / \mathrm{kg}$ ) (EPA 1998). EPA Region 9 PRGs for residential soils were exceeded in one sample for each chlordane, dieldrin, and heptachlor.

\subsection{Screening Risk Assessment}

An assessment was performed to determine if chlordane present in the soil below the Pesticide Rinse Area presents a potential threat to human health or the environment. The assessment was performed via computer modeling and spreadsheet calculations. The computer model used in this assessment was the Multimedia Environmental Pollutant Assessment System (MEPAS). MEPAS is a physics-based environmental analysis code that integrates source-term, transport, and exposure models for endpoints such as concentration, dose, or risk (Whelan et al. 1992). MEPAS was developed by PNNL for use in site-specific assessments such as this. Spreadsheet calculations were performed to illustrate the natural degradation or breakdown of the chlordane in the environment.

\subsubsection{Computer Modeling}

The conceptual site model consisted of the chlordane originating from the soil at a depth of $2 \mathrm{ft}$ and being transported by infiltration (leaching) through the vadose zone to the groundwater. The concrete pad was assumed not to be present to maximize the infiltration. Table 3.1 lists the site parameters used as inputs to MEPAS. Wherever possible, the most conservative parameter values were used. Two examples of this are degradation half-life and partition coefficient. A literature search of the half-life for chlordane indicated a range of 345 to 3,500 days. The most conservative value (3,500 days) was used for the calculations. Likewise, a range of 28 to 220 $\mathrm{mL} / \mathrm{g}$ was found for the partition coefficient, with $28 \mathrm{~mL} / \mathrm{g}$ being used in the model calculations. The impact of these two choices was that the chlordane was allowed to degrade at the slowest rate, while providing it the least amount of travel time (lowest adsorption). Other conservative choices included using the largest possible volumetric extent of chlordane contaminated soil and assuming that the entire volume was contaminated at the highest measured concentration. The 
modeling results indicate that the chlordane will never reach the groundwater due to the combination of adsorption and degradation.

Table 3.1. Input Parameter Values Used in MEPAS

\begin{tabular}{|c|c|c|c|}
\hline Parameter & Value & Units & Reference \\
\hline Waste Zone Thickness & 10 & $\mathrm{ft}$ & $\begin{array}{l}\text { Assumed from } \\
\text { contaminant } \\
\text { data }\end{array}$ \\
\hline Waste Zone Length & 34 & $\mathrm{ft}$ & $\begin{array}{l}\text { Assumed from } \\
\text { concrete pad } \\
\text { dimensions }\end{array}$ \\
\hline Waste Zone Width & 34 & $\mathrm{ft}$ & $\begin{array}{l}\text { Assumed from } \\
\text { concrete pad } \\
\text { dimensions }\end{array}$ \\
\hline Soil Concentration & 10 & $\mathrm{mg} / \mathrm{kg}$ & $\begin{array}{l}\text { Extrapolated } \\
\text { from } \\
\text { contaminant } \\
\text { data }\end{array}$ \\
\hline Dry Bulk Density & 1.83 & $\mathrm{~g} / \mathrm{cm}^{3}$ & estimated \\
\hline Total Porosity & 36.0 & $\%$ & computed \\
\hline Effective Porosity & 36.0 & $\%$ & assumed \\
\hline Moisture Content & 16.0 & $\%$ & computed \\
\hline Chlordane Kd & 28 & $\mathrm{~mL} / \mathrm{g}$ & ARS* \\
\hline Darcy Infiltration Rate & 12.94 & $\mathrm{~cm} / \mathrm{yr}$ & assumed \\
\hline Field Capacity & 15 & $\%$ & assumed \\
\hline Sand & 60 & $\%$ & assumed \\
\hline Silt & 37 & $\%$ & assumed \\
\hline Clay & 3 & $\%$ & assumed \\
\hline Soil Type Coefficient & 4.64 & none & computed \\
\hline Saturated Hydraulic Conductivity & 600 & $\mathrm{ft} /$ day & assumed \\
\hline Thickness of Vadose Zone & 49 & $\mathrm{ft}$ & measured \\
\hline Longitudinal Dispersivity & 0.49 & $\mathrm{ft}$ & computed \\
\hline $\mathrm{pH}$ of Soil & 7 & none & assumed \\
\hline Chlordane half-life & 3,500 & days & ARS* \\
\hline
\end{tabular}

*ARS Agriculture Research Service Pesticide Properties Database http://www.arsusda.gov/rsml/ppdb2.html 


\subsubsection{Natural Degradation}

The following equation was used to estimate the loss of chlordane over time due to natural degradation.

$$
M_{t}=M_{o} e^{-\lambda t}
$$

$$
\text { where } \begin{aligned}
& \mathrm{M}_{\mathrm{t}}=\text { mass remaining at time } \mathrm{t}(\mathrm{g}) \\
& \mathrm{M}_{\mathrm{o}}=\text { initial mass at time }=0(\mathrm{~g}) \\
& \lambda=\text { decay rate coefficient }(1 / \mathrm{yr}) \\
& \mathrm{t}=\text { time }(\mathrm{yr})
\end{aligned}
$$

Figure 3.2 shows the results of this analysis, where the chlordane inventory drops rapidly due to its relatively short half-life of 9.58 years (3,500 days). This loss rate is extremely significant considering the long travel times caused by the large partition coefficient used. In essence, the chlordane is moving slowly and decaying rapidly.

\subsection{Conclusions and Recommended Actions}

At the Pesticide Rinse Area, only one out of 15 samples exceeded the industrial screening criteria for chlordane; all other pesticides were below the screening criteria. A screening risk assessment was conducted to evaluate the significance of this contamination. Modeling results indicate that chlordane will never reach the groundwater as a result of adsorption and degradation. Natural degradation will reduce the inventory of chlordane to insignificant levels within 80 years. The results of the assessment show that the chlordane in the soil does not pose a human health risk due to three primary factors: 1) low initial inventory, 2) high partition coefficient, and 3) short half-life. Based on these results, and given the fact that a follow-up comparison revealed that all chlordane concentrations measured at the Pesticide Rinse Area are below the EPA Region 9 PRG for industrial soils, PNNL, as well as Fort Lewis and EPA, have concluded that this site does not pose an unacceptable risk to human health or the environment. This conclusion is in concurrence with the previous assessment. As a result, no further action is necessary at this site under CERCLA. However, the Pesticide Rinse Area should be included in a future Institutional Control Plan for Fort Lewis. If the land use for this site changes to residential, EPA should be notified and the risk assessment should be updated. The Pesticide Rinse Area should also be included in the Fort Lewis Logistics Center 5-year reviews because contamination is being left in place. These recommendations should be addressed formally in an Explanation of Significant Difference (ESD) to the Logistics Center Record of Decision (ROD). 


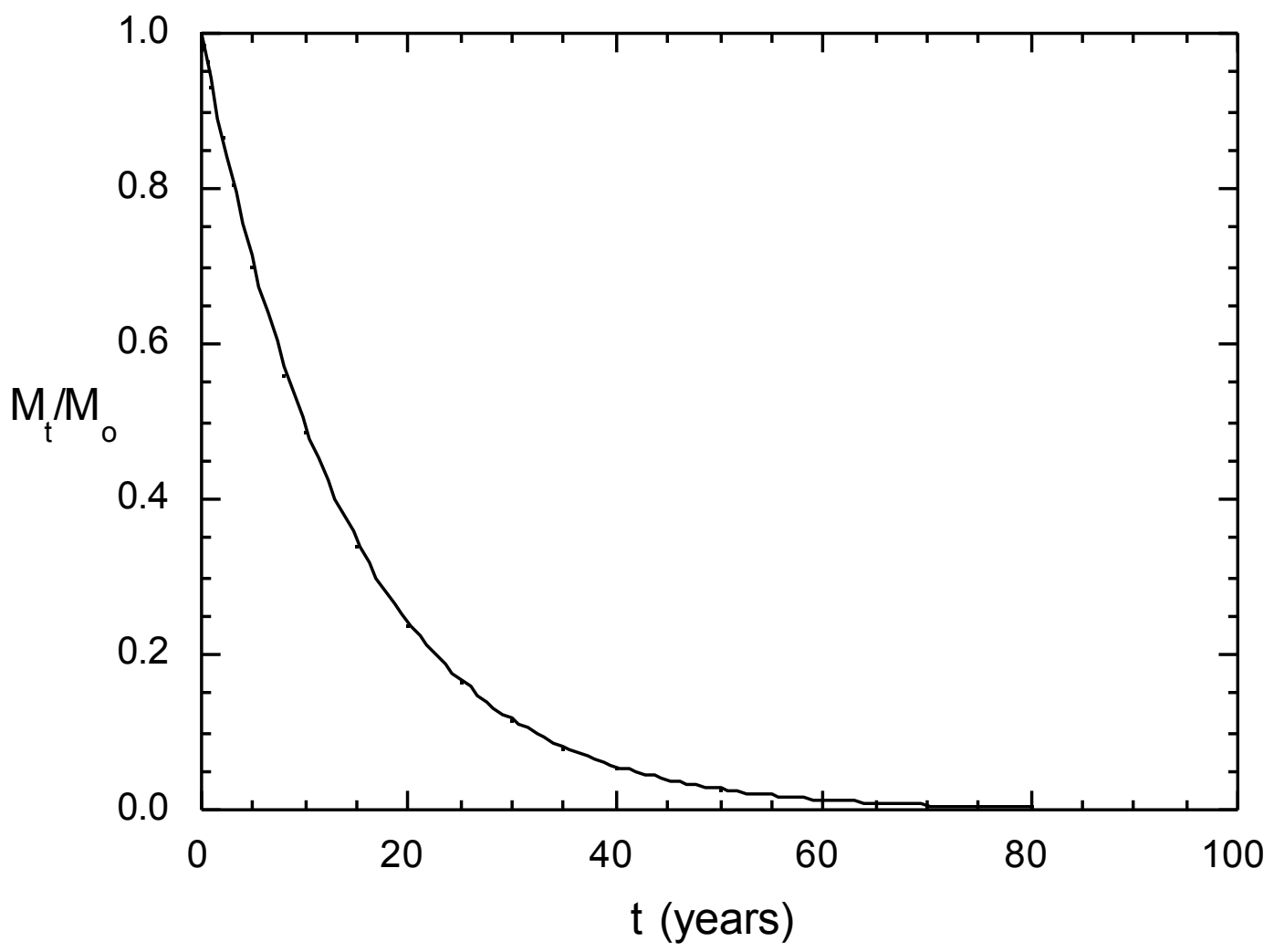

Figure 3.2. Ratio of Chlordane Mass Remaining to Initial Chlordane Mass as a Function of Time 


\subsection{Old Fire Fighting Training Pit}

The Old Fire Fighting Training Pit is located on the north side of Taxiway \#2 at Gray Army Airfield (Figure 4.1). It was used between 1962 and 1982 for fire-response training where flammable liquid waste materials were pumped into the pit and ignited.

\subsection{Summary of Previous Analytical Results}

Two previous field investigations were conducted at the Old Fire Fighting Training Pit. In September 1986, a survey was performed to assist in the preparation of a Resource Conservation and Recovery Act (RCRA) Part B permit application for Fort Lewis. Twenty test pits were dug within a 100-ft-diameter area thought to encompass the Old Fire Fighting Training Pit. Twelve composite soil samples were collected and analyzed for 56 SVOCs using EPA Method 8270. All compounds were found to be below their respective method detection limits (MDLs). However, field personnel noted visible oily contamination and hydrocarbon odors. Air monitoring with a photoionization detector (PID) indicated concentrations ranging from 1 to 15 PPMv (U.S. Army 1990).

Based on the results of this survey, EPA requested that a second sampling effort be conducted to more accurately characterize the site, and specifically, to determine if contamination was present at depth. In September 1987, three borings were advanced to a depth of $10 \mathrm{ft}$ using a 4-indiameter hollow-stem auger. Eight soil samples were collected using a split-spoon sampler and analyzed for SVOCs and VOCs, pesticides and PCBs, and dioxins and dioxin homologues. Trace amounts of dioxins, xylenes, methylene chloride, and some SVOCs were detected in some of the samples. Dioxin was also found in the field blank and bis(2-ethylhexyl)phthalate was encountered in a rinsate blank (U.S. Army 1990). Tetra Tech (1993) deemed these results questionable because contaminants were also detected in the field and rinsate blanks.

Between September 1993 and July 1994, Woodward-Clyde conducted a limited field investigation to determine if the previous practices at the Old Fire Fighting Training Pit resulted in contamination of the uppermost aquifer beneath the site (Woodward-Clyde 1994). The investigation included installation of three monitoring wells, an evaluation of the groundwater gradient, and groundwater sampling and analysis.

Groundwater samples were collected in November and December 1993 and analyzed for VOCs, SVOCs, low-level PCBs, metals, cyanide, and dioxins and furans. No visual or olfactory evidence of contamination was observed during monitoring well installation. No VOCs, SVOCs, PCBs, cyanide, or toxic metals were detected in any of the groundwater samples. Trace 


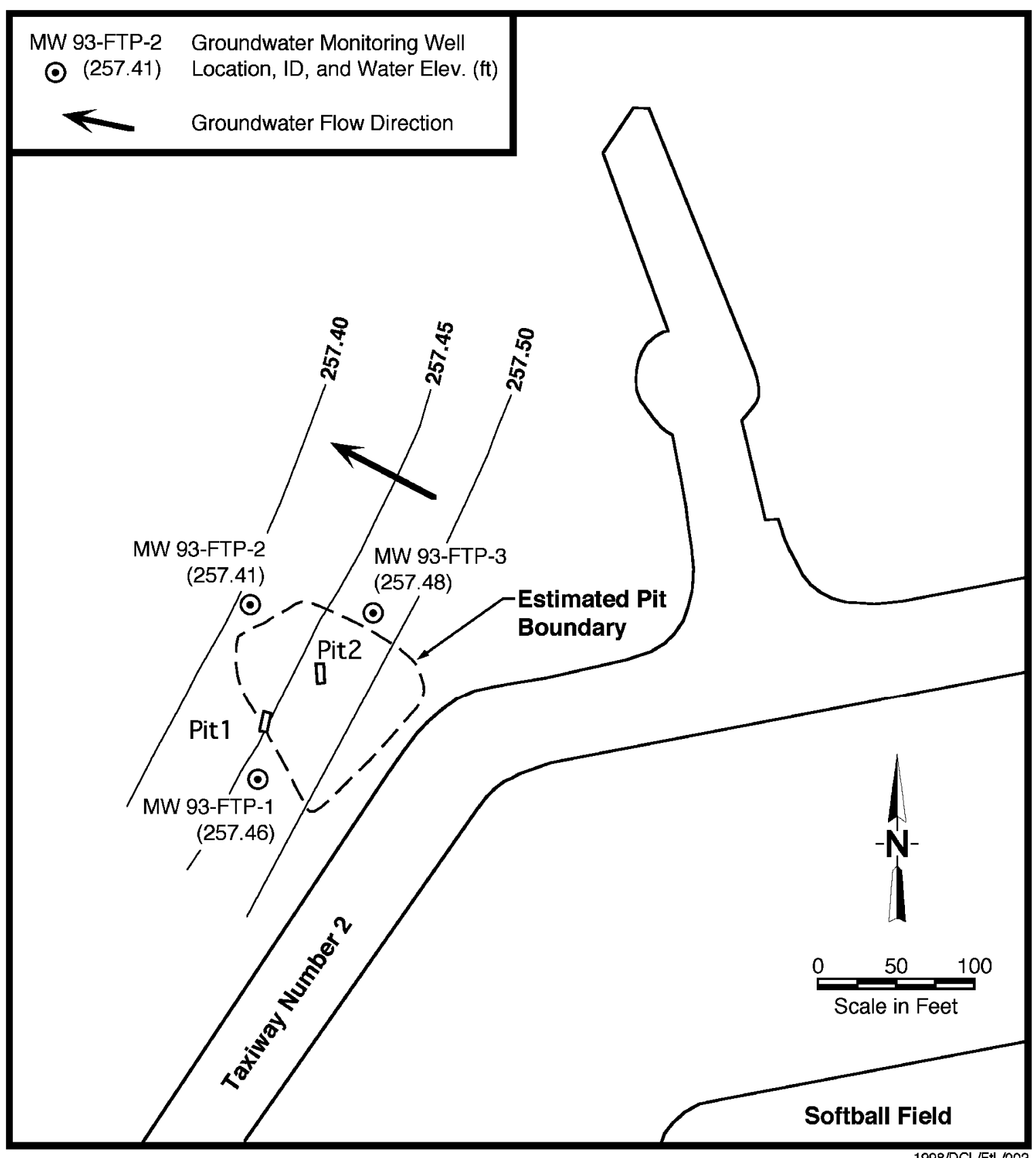

Figure 4.1. Location Map for the Old Fire Fighting Training Pit and Confirmatory Soil Sampling Locations (From October 6, 1998) 
(low parts per quadrillion) levels of dioxins were apparently detected in some samples, but these detects were attributed to laboratory instrument carryover from spiked samples.

Because no contaminants were detected in soil or groundwater at the Old Fire Fighting Training Pit, the site was not considered to present any risk to human health or the environment, and therefore, recommended for no further action. However, because the early fieldwork did suggest the presence of VOCs (oily contamination, hydrocarbon odors, PID detects), a final confirmatory soil sampling was conducted. PNNL recommended two sampling sites with soil samples collected at depths of 1, 3, and $10 \mathrm{ft}$. The samples were analyzed for VOCs and TPH.

\subsection{Confirmatory Soil Sampling Results}

Two test pits within the Old Fire Fighting Training Pit were sampled for VOCs (EPA Method 8260) and TPH-Diesel (Ecology Method WTPH-D) on October 6, 1998. A hand-held PID was used to locate areas of possible contamination for sampling. A small quantity of surface soil was collected and placed in a plastic bag. The bag was shaken and the PID was then used to measure contamination in the head space inside the bag. Very little evidence of contamination was found with this technique. At one location, a concentration of 2 PPMv was measured, but was not repeatable. Pit 1 was located at this site. No other PID "hits" were found. Pit 2 was located in a barren area near the center of the site. The pits were dug with a backhoe. Approximate locations are shown in Figure 4.1. Samples were collected at 1, 3 and $10 \mathrm{ft}$ from each pit. The analytical results are presented in Table 4.1 .

Table 4.1. Old Fire Fighting Training Pit Confirmatory Soil Sampling Results

\begin{tabular}{|c|c|c|}
\hline Sample Number-Depth & All VOCs (mg/kg) & TPH (mg/kg, Fuel Oil \#2) \\
\hline Pit 1-1 & $\mathrm{U}^{*}$ & 75 \\
\hline Pit 1-3 & $\mathrm{U}^{*}$ & 45 \\
\hline Pit 1-10 & $\mathrm{U}^{*}$ & $26\left(\mathrm{U}^{*}\right)$ \\
\hline Pit 2-1 & $\mathrm{U}^{*}$ & $27\left(\mathrm{U}^{*}\right)$ \\
\hline Pit 2-3 & $\mathrm{U}^{*}$ & $26\left(\mathrm{U}^{*}\right)$ \\
\hline Pit 2-3(Duplicate) & $\mathrm{U}^{*}$ & $25\left(\mathrm{U}^{*}\right)$ \\
\hline Pit 2-10 & $\mathrm{U}^{*}$ & $26\left(\mathrm{U}^{*}\right)$ \\
\hline Blank & $\mathrm{U}^{*}$ & $25\left(\mathrm{U}^{*}\right)$ \\
\hline
\end{tabular}

*U indicates not detected

No VOCs were found above the detection limit for any of the samples. Fuel Oil \#2 was detected in the two shallowest samples from Pit 1 . No hydrocarbons above the detection limit were found 
at $10 \mathrm{ft}$. Ecology has established Model Toxics Control Act (MTCA) Method A petroleum interim cleanup levels for soils (Ecology 1997). These levels are $200 \mathrm{mg} / \mathrm{kg}$ for TPH-Diesel and TPH-Other. The level for TPH-Gasoline is $100 \mathrm{mg} / \mathrm{kg}$. The results in Table 1 indicate that some residual hydrocarbons still exist at the Old Fire Fighting Training Pit; however, the levels are below regulatory concern.

\subsection{Conclusions and Recommended Action}

Based on results of previous characterization work and the confirmatory soil sampling results, PNNL, and accordingly Fort Lewis and EPA, have concluded that the Old Fire Fighting Training Pit is unlikely to pose any unacceptable risk to human health or the environment. This conclusion is in concurrence with previous the assessment. As a result, no further action is recommended under CERCLA. 


\subsection{Illicit PCB Dump Site}

The Illicit PCB Dump Site is located eight miles east of the main Fort Lewis cantonment area, northeast of the intersection of Pole Line Road and East Gate Road (Figure 5.1). It is on military reservation land within a dense forest that is part of the West Sterling Timber Sale Area (Tetra Tech 1993). The site is situated in a large semi-rectangular clearing and following initial discovery, was surrounded by a barbed-wire fence strung between wooden and metal posts. Its dimensions are $400 \mathrm{ft}$ long by 30 to $100 \mathrm{ft}$ wide. Currently, the dump is covered with an engineered clay and topsoil cap that is reportedly up to $3 \mathrm{ft}$ thick. Until recently, the clay and topsoil cap was covered with dense vegetation including grasses, Scotch Broom, coniferous saplings, and fungi.

\subsection{Summary of Previous Analytical Results}

A timber contractor who was inspecting trees in the West Sterling Timber Sale Area discovered the Illicit PCB Dump Site on November 16, 1983. According to the contractor, air at the site had a strong mothball-like odor and an oily, waxy substance was clinging to the vegetation and floating on puddles of water on the adjacent gravel road. The contractor notified the USACE forester at Fort Lewis regarding the suspected chemical spill. The USACE forester notified the Fort Lewis environmental office, which then contacted Ecology and EPA. Fort Lewis requested emergency cleanup assistance from USACE.

Following notification, USACE conducted an emergency remedial investigation and clean-up action. This included sampling the spilled substance, excavating contaminated soils, covering the dumpsite, and conducting a limited groundwater investigation. Detailed descriptions of these tasks are presented in U.S. Army (1990) and summarized below.

The initial remedial activity included identification of the spilled substance. An EPA Technical Assistance Team systematically collected samples of the material from 17 locations on a sampling grid. Chemical analysis revealed that it consisted of 25\% PCB (Aroclor 1260) and 75\% trichlorobenzene (Tetra Tech 1993).

Subsequent to sampling, 1869 tons of contaminated soils were excavated from locations shown in Figure 5.1. Initially, Ecology required the removal of all soils with PCB concentrations greater than $1 \mathrm{mg} / \mathrm{kg}$ (Tetra Tech 1993). It became evident during the excavation that this requirement could not be met as a result of the apparent depth of contamination. Ecology then modified the requirement to $50 \mathrm{mg} / \mathrm{kg}$. The modified requirement was met with the exception of two small areas where soils with PCB concentrations of 280 and $390 \mathrm{mg} / \mathrm{kg}$ were not removed. Ecology indicated that they would have liked to have more soil removed; however, because Fort 


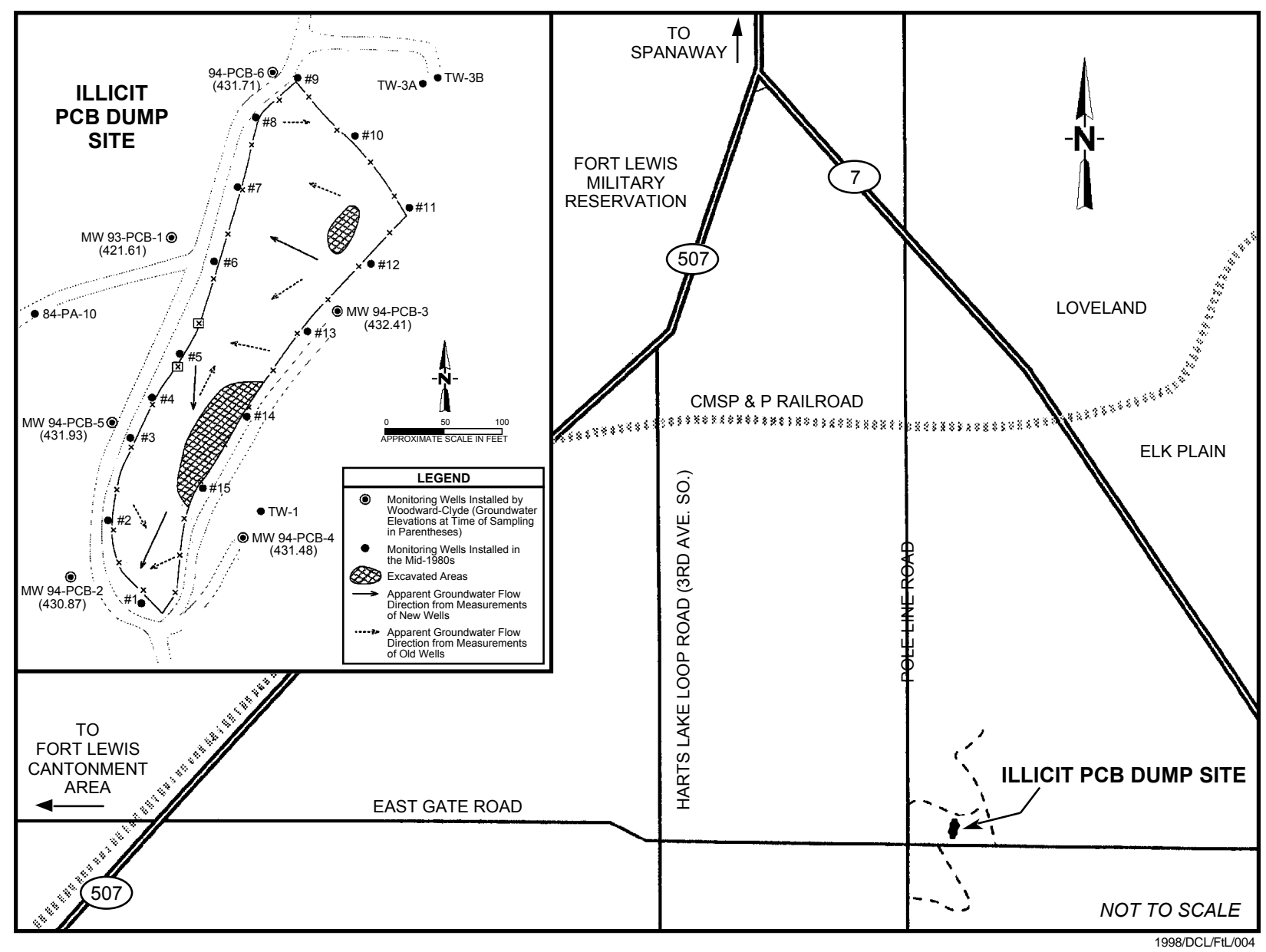

Figure 5.1. Location Map for the Illicit PCB Dump Site

Lewis could not obtain immediate funding or contracts for additional soil removal, and it was feared that infiltrating rain might mobilize the PCBs, they agreed to capping the site followed by additional monitoring (correspondence dated October 5, 1984, from Ecology to EPA).

The contaminated soils were shipped to a licensed disposal facility in Arlington, Oregon. The excavated areas were then backfilled with granular material obtained from a nearby borrow source. To prevent leaching of the contaminants that were left in place, the entire spill area was covered with a low-permeability clay and topsoil cap. The permeability of the cap is $10^{-6} \mathrm{~cm} / \mathrm{sec}$ and $10^{-8} \mathrm{~cm} / \mathrm{sec}$ for 96 percent and 100 percent compaction, respectively. A barbed-wire fence was installed around the edge of the cap to limit access. 
Ecology requested that a remedial investigation be performed at the site after completion of excavation and capping. In 1984, three monitoring wells were installed to assess potential groundwater contamination in the uppermost aquifer beneath the site. In addition, USACE conducted a seismic refraction survey to characterize the stratigraphy of the site and to clarify groundwater flow direction. Results of the survey indicated that a relatively impermeable till layer was present at a depth of $\sim 12 \mathrm{ft}$ (Tetra Tech 1993). Because of this till, contamination of the Vashon Drift Aquifer was ruled out. It was deemed possible at the time that contaminants (presumably trichlorobenzene) could migrate offsite via shallow perched groundwater.

Groundwater samples collected from two of the wells had trace concentrations of trichlorebenzene. PCB concentrations were less than the MDL of $0.1 \mu \mathrm{g} / \mathrm{L}$ (U.S. Army 1990). The Washington State groundwater quality criterion for PCBs is $0.01 \mu \mathrm{g} / \mathrm{L}$.

Fifteen additional monitoring wells were installed around the perimeter of the excavated area in late 1984 and early 1985. Well 84-PA-10 was also installed a short distance west of the dump site. No groundwater quality or water-level data have been reported for well 84-PA-10 or the other wells.

In 1993-94, Woodward-Clyde conducted a limited field investigation at the Illicit PCB Dump Site to determine if PCBs or trichlorobenzene were present at significant concentrations in the uppermost groundwater system beneath the site. Secondary objectives were to 1) evaluate the potential for contaminant migration based on the local groundwater flow direction, 2) evaluate the integrity of the clay and topsoil cap, and 3) determine if well 84-PA-10 had been properly abandoned. Layne, under the supervision of Woodward-Clyde, installed six groundwater monitoring wells around the perimeter of the site. Well 93-PCB-1 was installed in November 1993 and the other five wells were installed in April 1994. Samples were collected on April 18, 1994. PCBs were analyzed by EPA Modified Method 8080 with low-level quantitation limits and the chlorinated hydrocarbons were analyzed by EPA Method 8121.

PCBs and trichlorobenzene were not detected in the groundwater samples. Woodward-Clyde (1994) noted that the uppermost aquifer appears to be seasonal and does not appear to have a well-defined gradient. Further, the clay and topsoil cap appears to be in satisfactory condition; however, the potential for root penetration of the cap was not assessed. Monitoring wells around the perimeter of the cap and other wells installed during the 1980s, such as 84-PA-10, were in poor condition and recommended for abandonment according to the State of Washington Minimum Standards for Construction and Maintenance of Wells (WAC 173-160).

In 1998, PNNL evaluated the potential for encroaching plants (scotch broom [Cytisus scoparius] in particular) to translocate PCBs. No information regarding the root depth of scotch broom could be found. Based on root growth of scrubs comparable in size to scotch broom, it is 
apparent that the roots could potentially reach depths in excess of $12 \mathrm{ft}$ (McDougall 1949). However, because the climate at Fort Lewis is humid, it is not likely that the roots would need to extend that deep (McDougall 1949). Data on uptake of PCBs in scotch broom could not be found in the literature. A review of uptake of PCBs in plants suggests that PCBs are taken up by plants, but there is no definitive evidence to suggest that they are translocated within the plant, that is, PCBs adsorbed by plant roots will stay in the plant roots (Bell 1992).

\subsection{Conclusions and Recommended Actions}

As a result of the removal action, the installation and current condition of the cap, and the absence of contamination in groundwater, no threat to public health or the environment is expected at the Illicit PCB Dump Site. Recommendations to 1) abandon the wells installed during the 1980 s to prevent these wells from being a potential route for contaminant migration and 2) install a 6-ft-high chain link fence around the site to prevent any disturbance of the site, have been completed by USACE. The cap has also been debrushed. Additional groundwater monitoring over a two-year period is in progress. Two sampling rounds have been completed (March and July 1999) and two more rounds should be completed; one in the fall and one in the winter. The samples should be analyzed for PCBs and triclorobenzene. If no contamination is detected, it is recommended that further sampling be discontinued and the site closed under CERCLA. Additional investigation may be necessary if contamination is detected. Either way, the site should be included as part of the future Institutional Control Plan for Fort Lewis and the Logistics Center 5-year reviews because contamination is being left in place. These recommendations should also be addressed in the ESD to the Logistics Center ROD. 


\subsection{Battery Acid Pit}

The Battery Acid Pit is located in the North Uses Area of the Logistics Center (Figure 6.1). It was used from 1971 to 1976 for discarding electrolyte solutions from vehicle batteries. The Battery Acid Pit was not considered as a potential TCE source area during the Logistics Center Remedial Investigation/Feasibility Study, but was included for confirmational soil sampling in the ROD because of the potential for lead contamination. The Installation Restoration Action Plan (Public Works 1998); however, lists chlorinated solvents, acids, and solvents as the contaminants of concern. In 1982, the pit was filled and covered with soil.

\subsection{Summary of Previous Analytical Results}

In 1986, soil samples were collected from near the surface of the Battery Acid Pit and every 2 or $3 \mathrm{ft}$ to a depth of $14 \mathrm{ft}$. The samples were analyzed for $\mathrm{pH}$ and EP toxicity for eight metals. The soil $\mathrm{pH}$ ranged from 6.0 to 7.5. Mercury was detected in the EP toxicity tests at concentrations ranging from 0.0041 to $0.0059 \mathrm{mg} / \mathrm{L}$ leachable mercury (in soils from 3 to $7 \mathrm{ft}$ deep) (Woodward-Clyde 1993).

In June and July of 1993, Woodward-Clyde conducted confirmational soil sampling at the Battery Acid Pit to identify and characterize hazardous or toxic soil constituents. Four soil borings were drilled in an area identified by the Army as the Battery Acid Pit (Figure 6.1). Soil from the first three borings showed no evidence of reaction with acidic solutions. The fourth boring encountered soil with a faint sulfurous odor and yellowish staining. Samples collected from this boring were analyzed for total metals, Toxicity Characteristic Leaching Procedure (TCLP) metals, and $\mathrm{pH}$. Total arsenic exceeded the EPA Region 10 risk level of $1.0 \times 10^{-6}$ and total cadmium exceeded the MTCA Method A screening level. Analytical results for TCLP metals indicated that the soil is not a dangerous or extremely hazardous waste. The $\mathrm{pH}$ results (6.0 to 6.9) indicated that the soil was not impacted by acidic solutions. These results are documented in Woodward-Clyde (1993). Facility personnel stated that a battery acid pit was located where the soil borings were drilled and indicated that the stained soil observed in the fourth boring could be attributed to leaking electrolyte solutions from batteries, which were commonly stored on pallets in this area. Facility personnel also stated that they believed two former battery acid pits were located immediately outside the former Battery Service Building and beneath a concrete slab constructed during expansion of the building.

Additional investigation was planned to find conclusive evidence of the Battery Acid Pit. Two test pits were excavated near the former Battery Service Building with a backhoe by WoodwardClyde in September 1994. One shallow pit was dug in the area where samples were collected from a soil boring in September 1986. This is also the location where the four exploratory soil 


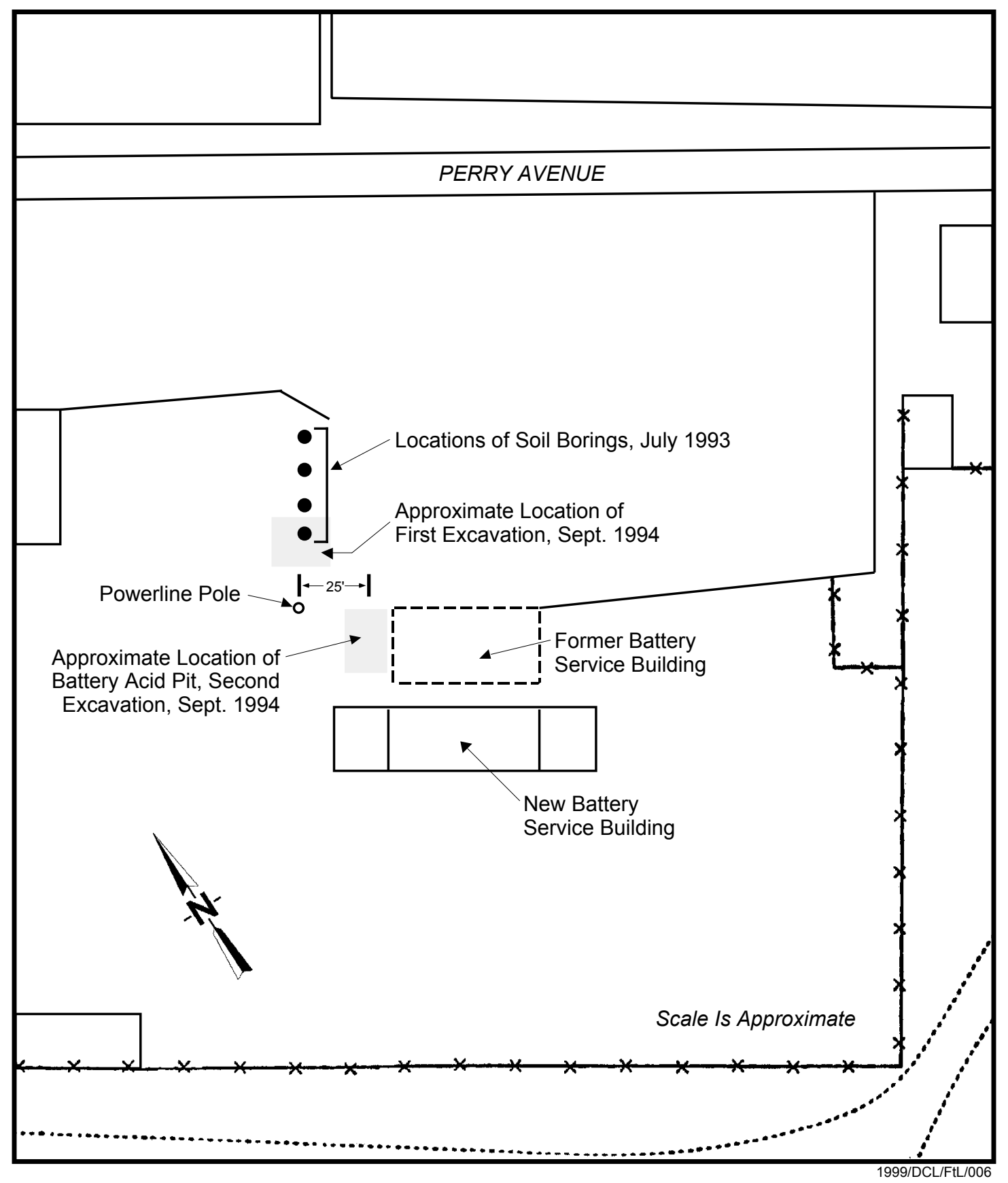

Figure 6.1. Location Map for the Battery Acid Pit 
borings were drilled in July 1993. The pit was excavated to a depth of $2 \mathrm{ft}$, when concrete building footings and an active cast iron water pipeline were encountered. Encountering these objects strongly suggested that a battery acid pit was never located in this area. During the excavation of this test pit, an employee of the Logistics Center indicated that he had uncovered the Battery Acid Pit $\sim$ two months earlier when he was grading the area following demolition of the former Battery Service Building. The demolition of this building was followed by construction of a new Battery Service Building adjacent to the older building. The employee indicated that the Battery Acid Pit was located near the northern corner of the former Battery Service Building. The second test pit was excavated at this location following approval by Fort Lewis and USACE.

The second test pit was excavated to a maximum depth of $14 \mathrm{ft}$. Soil samples were collected at $0.5,4,10$, and $13 \mathrm{ft}$ and analyzed for the eight RCRA metals plus copper and zinc. The samples from 10 and $13 \mathrm{ft}$ were analyzed for the same metals by TCLP. Field and laboratory measurement of $\mathrm{pH}$ was also performed. The outline of the former pit could clearly be seen in the walls of the excavation. The cobbles and gravels present in the central portion of the pit were bleached to light gray and white. Gravel and cobble materials surrounding the bleached zone exhibited a prominent yellow to yellow-orange staining. Small crystals of what appeared to be gypsum were interspersed through the bleached soils. These observations suggest that acidic solutions were dumped into the pit causing iron oxides to leach from the sediments. As acidic solutions react with minerals in the sediment, they become neutralized and dissolved iron will precipitate as an oxide. This process could result in the yellow to yellow-orange staining. It is also possible that the iron oxide staining was the result of natural weathering and the bleached areas occurred as the acid dissolved these naturally formed iron oxides. Additionally, as sulfuric acid solutions become neutralized, the resulting solution will contain high concentrations of sulfate and calcium that can lead to the precipitation of gypsum.

The only metal detected at levels of concern within the test pit was lead. Sample depth, lead concentrations, and $\mathrm{pH}$ are shown in Table 6.1 . Concentrations ranged from 14 to $2,300 \mathrm{mg} / \mathrm{kg}$, and those in the 0.5-, 4-, and 10-ft samples exceeded the $400 \mathrm{mg} / \mathrm{kg}$ screening level for children by EPA (OSWER 1998).

The TCLP results from 10 and $13 \mathrm{ft}$ were $3.1 \mathrm{mg} / \mathrm{L}$ and below detection, respectively. Comparison of the total lead concentration $(468 \mathrm{mg} / \mathrm{kg}$ ) (Woodward-Clyde 1998) and the TCLP lead result $(3.1 \mathrm{mg} / \mathrm{L})$ for the sample collected from $10 \mathrm{ft}$ suggest that if TCLP tests were run on the samples collected from $0.5 \mathrm{ft}(2,300 \mathrm{mg} / \mathrm{kg})$ and $4 \mathrm{ft}(1,270 \mathrm{mg} / \mathrm{kg})$, the resultant extract would exceed the $5 \mathrm{mg} / \mathrm{L}$ TCLP limit. This would result in the soil being classified as a dangerous waste, if it were excavated. 
Table 6.1. Lead and pH Results for Battery Acid Pit Soil Samples

\begin{tabular}{|c|c|c|}
\hline Depth (ft) & Pb Conc. $(\mathbf{m g} / \mathbf{k g})$ & $\mathbf{p H}$ (field/lab) \\
\hline 0.5 & 2300 & $4.22 / 5.26$ \\
\hline 4 & 1270 & $3.89 / 3.88$ \\
\hline 10 & 436 & $3.80 / 3.93$ \\
\hline 13 & 14 & $4.15 / 4.24$ \\
\hline
\end{tabular}

The field $\mathrm{pH}$ results for the Battery Acid Pit soil samples ranged from 3.8 to 4.2. The laboratory results ranged from 3.9 to 5.3. The values are not low enough to classify the soils as a dangerous waste $(\mathrm{pH} \leq 2)$; however, comparison with $\mathrm{pH}$ values from uncontaminated soils ( $\mathrm{pH} 6.0$ to 7.5) demonstrates that the Battery Acid Pit soils have been impacted by acidic solutions.

Both dissolved and total lead were analyzed in the Logistics Center monitoring wells during 1996-97. None of the wells exceeded the EPA maximum contaminant level for lead $(15 \mu \mathrm{g} / \mathrm{L})$. Several wells had total lead concentrations between the detection limit and $12 \mu \mathrm{g} / \mathrm{L}$; however, these measurements were not reproducible. In addition, the wells in which lead was detected did not fit a pattern consistent with the Battery Acid Pit as the source. Lead is well known for being strongly adsorbed to soil minerals and forming very insoluble compounds under most natural groundwater and soil conditions (McBride 1994; Boggess 1977). Under acidic conditions, lead can be mobilized, but the acid solutions in the Battery Acid Pit were largely neutralized. Therefore, lead would not be expected to move any significant distance from the site.

Originally, the Battery Acid Pit was scheduled to have an EE/CA performed by PNNL in 1998. In fact, a draft EE/CA containing various remedial alternatives was prepared and presented to Fort Lewis and EPA. After consultation, it was decided that the site should be considered for no further action. It was agreed that a health impact assessment would be conducted to support the no further action scenario.

\subsection{Health Impact Assessment for Exposure to Lead}

Exposure to residual lead in the Battery Acid Pit was evaluated for a worker assumed to come into direct contact with the contamination and to be exposed to airborne particulate contamination. The exposure analysis was performed assuming there was no protective cover at the site, and that the worker spent 8 hours per day, 250 days per year in the vicinity of the contamination. An area of 25 by $15 \mathrm{ft}$, with a surface lead contamination of $2,300 \mathrm{mg} / \mathrm{kg}$ was used. Three exposure pathways were considered; inhalation of airborne particulate material, ingestion of soil, and dermal contact with soil. 


\subsubsection{Inhalation of Contaminants from Soil Suspension}

When measured soil concentrations are available at the exposure point, the exposed individuals are assumed to be exposed to contaminants released from the soil by suspension of soil particles. The air concentration is evaluated using the particle emission factor method and the soil concentration over the exposure period is assumed to be constant. The contribution to air concentration from particle emissions is determined as follows.

$$
\mathrm{PEF}=\mathrm{Q} / \mathrm{C} \frac{3600}{0.036\left(1-\mathrm{VU}_{\mathrm{n}}\left(/ \mathrm{U}_{\mathrm{t}}\right)^{3} \mathrm{~F}(\mathrm{x})\right.}
$$

where $\mathrm{PEF}=$ particle emission factor $\left(\mathrm{m}^{3} / \mathrm{kg}\right)$

$\mathrm{Q} / \mathrm{C}=$ inverse of mean concentration at center of a square source $\left(\mathrm{g} / \mathrm{m}^{2}-\mathrm{s}\right.$ per $\mathrm{kg} / \mathrm{m}^{3}$ )

$\mathrm{V}=$ fraction of land covered by vegetation (unitless)

$\mathrm{U}_{\mathrm{m}} \quad=\quad$ mean annual windspeed $(\mathrm{m} / \mathrm{s})$

$\mathrm{U}_{\mathrm{t}}=$ equivalent threshold value of windspeed at 7 meters $(\mathrm{m} / \mathrm{s})$

$\mathrm{F}(\mathrm{x})=$ function depending on $\mathrm{U}_{\mathrm{m}} / \mathrm{U}_{\mathrm{t}}$ derived using Cowherd et al. (1984) (unitless)

The concentration of a chemical in air is evaluated as follows, with contributions included for volatilization and particle suspension.

$$
\mathrm{C}_{\mathrm{ds}}=\mathrm{C}_{\mathrm{s}} \frac{\mathrm{F}_{\mathrm{ds}}}{\mathrm{PEF}}
$$

where $\mathrm{C}_{\mathrm{ds}}=$ air concentration for exposure to airborne material above contaminated soil $\left(\mu \mathrm{g} / \mathrm{m}^{3}\right)$

$\mathrm{C}_{\mathrm{s}}=$ average soil concentration over the exposure period $(\mu \mathrm{g} / \mathrm{kg})$

$\mathrm{F}_{\mathrm{ds}}=$ fraction of days in a year that exposure occurs

The evaluation was performed using the following parameter values.

$$
\begin{array}{lll}
\mathrm{Q} / \mathrm{C} & = & 82.72 \mathrm{~g} / \mathrm{m}^{2}-\mathrm{s} \text { per } \mathrm{kg} / \mathrm{m}^{3}(\mathrm{EPA} 1996) \\
\mathrm{V} & =0.0(\text { bare soil) } \\
\mathrm{U}_{\mathrm{m}} & =4.1 \mathrm{~m} / \mathrm{s}(\text { Cowherd et al. } 1985) \\
\mathrm{U}_{\mathrm{t}} & =11.32(\text { default from EPA } 1996)
\end{array}
$$




$\begin{array}{lll}\mathrm{F}(\mathrm{x}) & = & 0.06645 \text { evaluated using } \mathrm{U}_{\mathrm{m}} \text { and } \mathrm{U}_{\mathrm{t}} \text { (per Cowherd et al. 1985) } \\ \mathrm{C}_{\mathrm{s}} & =2.30 \mathrm{E} 6 \mu \mathrm{g} / \mathrm{kg} \text { (peak measured value) } \\ \mathrm{F}_{\mathrm{ds}}= & 0.6845 \mathrm{based} \text { on } 250 \text { work days } / \text { year } \\ \mathrm{PEF} & =2.619 \mathrm{E} 9 \mathrm{~m}^{3} / \mathrm{kg} \text { (based on above parameter values) }\end{array}$

The estimated air concentration is $6.01 \mathrm{E}-4 \mu \mathrm{g} / \mathrm{m}^{3}$. This concentration is well below the ambient background levels of $0.18 \mu \mathrm{g} / \mathrm{m}^{3}$ specified by Cal EPA (1996).

The transfer of lead to blood for the air inhalation pathway is based on the average air concentration to which the worker is exposed. Contributions to air concentration are included for particles suspended from the Battery Acid Pit. The blood level from air inhalation is estimated from the total air concentration and the intake conversion factor as follows.

$$
\mathrm{B}_{\mathrm{a}}=1.64 \mathrm{C}_{\mathrm{a}}
$$

where $\mathrm{B}_{\mathrm{a}}=$ blood lead level from air inhalation intake ( $\mu \mathrm{g} \mathrm{Pb} / \mathrm{dL}$ blood)

$1.64=$ intake conversion factor for transfer to blood from air inhaled $(\mu \mathrm{g} \mathrm{Pb} / \mathrm{dL}$ blood per $\mu \mathrm{g} \mathrm{Pb} / \mathrm{m}^{3}$ )

$\mathrm{C}_{\mathrm{a}}=$ average concentration of lead in air $\left(\mu \mathrm{g} / \mathrm{m}^{3}\right)$.

The resultant blood lead level is estimated to be $9.9 \mathrm{E}-4 \mu \mathrm{g} \mathrm{Pb} / \mathrm{dL}$ blood.

\subsubsection{Ingestion of Contaminated Soil}

The soil ingested by the worker is assumed to be entirely from the contaminated Battery Acid Pit. The ingestion rate is set to $25 \mathrm{mg} / \mathrm{d}$ as recommended by Cal EPA (1996). The reasonable maximum intake of $100 \mathrm{mg} / \mathrm{d}$ is not recommended for use with the lead model because "the model already considers the distribution of blood lead, which reflects variation in soil ingestion along with other variables." The transfer of lead from soil intake to the blood is reduced from that for lead in water and diet by a factor of $44 \%$ based on a study of soil lead and lead acetate in the diet of rats (Chaney et al. 1990; Cal EPA 1996). The blood level from soil ingestion is estimated from the soil ingestion rate and the intake conversion factor as follows.

$$
\mathrm{B}_{\mathrm{s}}=0.018 \mathrm{C}_{\mathrm{s}} \mathrm{I}_{\mathrm{s}} \mathrm{F}_{\mathrm{ds}}
$$


where $\mathrm{B}_{\mathrm{s}}=\quad$ blood lead level from soil ingestion intake ( $\mu \mathrm{g} \mathrm{Pb} / \mathrm{dL}$ blood)

$0.018=\quad$ intake conversion factor for transfer to blood for soil ingestion intake $(\mu \mathrm{g}$ $\mathrm{Pb} / \mathrm{dL}$ blood per $\mu \mathrm{g} \mathrm{Pb} /$ day)

$\mathrm{C}_{\mathrm{s}}=$ average concentration of lead in soil $(\mu \mathrm{g} / \mathrm{kg})$

$\mathrm{I}_{\mathrm{s}} \quad=\quad$ daily intake rate of soil by the worker $(\mathrm{kg} / \mathrm{d})$.

For a soil concentration of $2.3 \mathrm{E} 6 \mu \mathrm{g} / \mathrm{kg}$ soil, the median blood lead level is estimated to be 0.71 $\mu \mathrm{g} \mathrm{Pb} / \mathrm{dL}$ blood.

\subsubsection{Dermal Contact with Contaminated Soil}

Dermal contact with lead contaminated soil is evaluated assuming the worker comes in contact with the soil at the Battery Acid Pit or from soil transported to the work place (house dust). The worker is assumed to be exposed over a skin area of $0.5 \mathrm{~m}^{2}$, and the soil adheres to skin at a rate of $5 \mathrm{E}-3 \mathrm{~kg}$ soil $/ \mathrm{m}^{2}$. The blood level from soil dermal contact is estimated as follows per Carlisle and Wade (1992).

$$
\mathrm{B}_{\mathrm{d}}=0.0001 \mathrm{C}_{\mathrm{s}} \mathrm{I}_{\mathrm{d}} \mathrm{F}_{\mathrm{ds}}
$$

where $B_{d}=\quad$ blood lead level from soil dermal contact intake ( $\mu \mathrm{g} \mathrm{Pb} / \mathrm{dL}$ blood)

$0.0001=\quad$ intake conversion factor for transfer to blood for soil dermal contact $(\mu \mathrm{g}$

$\mathrm{Pb} / \mathrm{dL}$ blood per $\mu \mathrm{g} \mathrm{Pb} /$ day)

$\mathrm{C}_{\mathrm{s}}=$ average concentration of lead in soil $(\mu \mathrm{g} / \mathrm{kg})$

$\mathrm{I}_{\mathrm{d}} \quad=\quad$ daily contact rate with soil by the worker $(\mathrm{kg}$ soil/d).

The daily contact rate, $\mathrm{I}_{\mathrm{d}}$, is the product of the adherence factor and the skin area contacted, or $2.5 \mathrm{E}-3 \mathrm{~kg}$ soil $/ \mathrm{d}$. The median blood lead level from this pathway is estimated to be $0.40 \mu \mathrm{g}$ $\mathrm{Pb} / \mathrm{dL}$ blood.

\subsubsection{Summary of Blood Lead Levels}

The total potential blood lead level is the sum of the levels from each of the three pathways. The median blood lead level is then $1.11 \mu \mathrm{g} \mathrm{Pb} / \mathrm{dL}$ blood. The range of blood lead level is estimated based on the recommendation of Cal EPA (1996) that suggests the distribution of blood lead levels is log-normal with a geometric standard deviation 1.42. The distribution of blood lead levels is estimated in Table 6.2. 
Table 6.2. Blood Lead Levels at Various Median Percentiles

\begin{tabular}{|c|c|}
\hline Median Percentile & Mg Pb/dL blood \\
\hline $50 \%$ & 1.11 \\
\hline $90 \%$ & 1.74 \\
\hline $95 \%$ & 1.97 \\
\hline $98 \%$ & 2.28 \\
\hline $99 \%$ & 2.51 \\
\hline
\end{tabular}

These values are below the EPA guideline of $10 \mu \mathrm{g} \mathrm{Pb} / \mathrm{dL}$ blood. This indicates that exposure to residual lead in the Battery Acid Pit via the inhalation, ingestion, and dermal pathways are insignificant contributors to worker health risk.

\subsubsection{Exposure to Lead at 100 Meters}

In addition to these calculations, the MEPAS atmospheric model (Streile et al. 1996; Droppo and Buck 1996) was used to determine the exposure of an individual located $100 \mathrm{~m}$ from the site. The transport pathway of interest for this scenario is the atmospheric transport and dispersion of contaminated particulate that can be inhaled and deposited on surrounding soil and building surfaces.

The MEPAS atmospheric model uses a Gaussian dispersion model (Droppo and Buck 1996) that is limited to within $100 \mathrm{~m}$ of the center of the site. The receptor is assumed to be working in an area with a centroid $100 \mathrm{~m}$ south of the center of the Battery Acid Pit. Seattle-Tacoma International Airport (SEATAC) climatological data were used to model the dispersion and advection of contaminants in the atmosphere. A joint frequency distribution, associated with observations made for the years of 1988 through 1992, was used to simulate the wind speed and direction, and atmospheric stability (different degrees of unstable, stable, neutral buoyancy in the air) to estimate transport of contaminants associated with the site to the defined receptor point. The air and soil deposition concentrations were transferred to the exposure and risk modules for completion of the human health impact estimates.

The Battery Acid Pit is assumed to have contamination from the surface down to $0.5 \mathrm{ft}$ with an average concentration of $2,300 \mathrm{mg} / \mathrm{kg}$ of lead, as measured at the site. This concentration was used to compute the wind suspension potential of lead from the site. The Cowherd et al. (1985) model was used within the MEPAS Source Term Release Module (Streile et al. 1996) to compute the potential wind suspension of lead-contaminated soil particles. This model computes the rate (grams per year) of soil particles that are suspended by the wind using site characteristics and local climatology. 
One of the key parameters used to determine the release rate is the percent sand associated with the site. The higher the percent sand, the lower the suspension release rates. For the Battery Acid Pit, the percent sand was initially estimated to be $65 \%$. Because the computed release rate is very sensitive to this parameter, a range of parameter values was evaluated. The range was from $40 \%$ to $90 \%$. Table 6.3 shows the resulting suspension release rates as a function of percent sand. For the final analysis, the most conservative value of $40 \%$ was used. This provided the highest suspension release rate estimated for the Battery Acid Pit.

Table 6.3. Percent Sand, Soil Particle Suspension Rate, and Air Concentration

\begin{tabular}{|c|c|c|}
\hline Percent Sand & $\begin{array}{c}\text { Suspension Rate } \\
\mathbf{( g / y r})\end{array}$ & $\begin{array}{c}\text { Air Concentration at 100 m } \\
\left.\mathbf{( k g}^{\mathbf{3}} \mathbf{3}\right)\end{array}$ \\
\hline 40 & 1.1 & $7.9 \times 10^{-16}$ \\
\hline 65 & 0.17 & $1.3 \times 10^{-16}$ \\
\hline 90 & 0.037 & $2.7 \times 10^{-17}$ \\
\hline
\end{tabular}

Using the most conservative value for the percent sand in the soil ( $40 \%$ sand, or $60 \%$ clay), the blood $\mathrm{Pb}$ level was calculated to be $1.3 \mathrm{E}-6 \mu \mathrm{g} \mathrm{Pb} / \mathrm{dL}$ blood (equation 6.3). Again, this level is well below the EPA guideline of $10 \mu \mathrm{g} \mathrm{Pb} / \mathrm{dL}$ blood.

\subsection{Conclusions and Recommended Actions}

The results of the health impact assessment indicate that exposure to residual lead from the Battery Acid Pit for an individual working directly at the site will be minimal. In the analysis three primary exposure pathways were evaluated (inhalation, ingestion, and dermal contact). The estimated blood lead level contributions that result from the three exposure pathways were determined as follows: 1) inhalation 9.9E-4 $\mu \mathrm{g} \mathrm{Pb} / \mathrm{dL}$ blood, 2) ingestion $0.71 \mu \mathrm{g} \mathrm{Pb} / \mathrm{dL}$ blood and 3) dermal contact $0.40 \mu \mathrm{g} \mathrm{Pb} / \mathrm{dL}$ blood. The total potential median blood level concentration was calculated to be $1.1 \mu \mathrm{g} \mathrm{Pb} / \mathrm{dL}$ blood. At the 95th percentile, the blood level concentration was $2.0 \mu \mathrm{g} \mathrm{Pb} / \mathrm{dL}$ blood. These results can be compared to the EPA guideline level of $10 \mu \mathrm{g}$ $\mathrm{Pb} / \mathrm{dL}$ blood.

Exposure of an individual located $100 \mathrm{~m}$ from the site was also evaluated. In this case, only the inhalation exposure route is applicable. Using a conservative value for the percent sand in the soil (40\%), the blood lead level was calculated to be $1.3 \mathrm{E}-15 \mu \mathrm{g} \mathrm{Pb} / \mathrm{dL}$ blood.

Using relatively conservative assumptions in the assessment, the calculated blood lead level of a worker working directly at the site was more than factor of five below the EPA guideline. As a 
result, it is recommended that no further action be taken at the Battery Acid Pit under CERCLA, other than paving the site with asphalt (which has been completed) to remove any exposure potential altogether. If the land use changes to residential, EPA should be notified and the health impact assessment should be updated. The Battery Acid Pit should also be included in the Fort Lewis Logistics Center 5-year reviews because contamination is being left in place. Additionally, these recommendations should be addressed in the ESD to the Logistics Center ROD. 


\subsection{Conclusions and Recommendations}

On behalf of the installation, PNNL conducted independent site evaluations for four sites at Fort Lewis, Washington to determine their suitability for closure. Previous investigators recommended these sites for "No Further Action." The sites included the Storm Water Outfalls/IWTP, the Pesticide Rinse Area, the Old Fire Fighting Training Pit, and the Illicit PCB Dump Site. The Battery Acid Pit, originally scheduled for an EE/CA, was also considered here for no further action following consultation with Fort Lewis and EPA.

Initially, PNNL reviewed the site characterization and analytical data and performed site visits for each of the sites. A screening risk assessment was then conducted for the Pesticide Rinse Area, confirmatory soil sampling was performed at the Old Fire Fighting Training Pit, and a health impact assessment was completed for the Battery Acid Pit.

PNNL, and subsequently Fort Lewis and EPA, concur with the "No Further Action" recommendations for future response under CERCLA for the Storm Water Outfalls/IWTP, the Pesticide Rinse Area, and the Old Fire Fighting Training Pit. At the Storm Water Outfalls/IWTP, several samples contained concentrations of PAHs and arsenic that exceeded EPA Region 3 Risk-Based Screening Criteria for residential soils. However, these results were below applicable background concentrations. Only benzo(a)pyrene is above the more recent EPA Region 9 PRGs for industrial soils. The outfalls are subject to Clean Water Act requirements and as such, are covered by a NPDES permit.

For the Pesticide Rinse Area, only one of 15 samples exceeded the industrial screening criteria for chlordane applicable at the time of the analysis. The screening risk assessment was conducted to evaluate the significance of this contamination. Results from the modeling show that the chlordane will never reach the groundwater as a result of adsorption and degradation. Natural degradation will reduce the contaminant inventory to insignificant levels within 80 years. A follow-up comparison with EPA Region 9 PRGs for industrial soils indicated that none of the pesticides exceeded applicable levels and thus, are below levels of concern. This site should, however, be included in the future Fort Lewis Institutional Control Plan. EPA should be notified and the risk assessment should be updated if the land use changes to residential. The Pesticide Rinse Area should also be included in the Fort Lewis Logistics Center 5-year reviews because contamination is being left in place. These recommendations should be formally addressed in the ESD to the Logistics Center ROD.

Results of the confirmatory soil sampling conducted at the Old Fire Fighting Training Pit indicated no VOCs above MDLs. TPH analyses showed detectable levels; however, the concentrations were below the MTCA interim cleanup level of $200 \mathrm{mg} / \mathrm{kg}$. Based on these 
results and a review of previous characterization data, this site does not pose a significant risk to human health or the environment and no further action is recommended.

No threat to public health or the environment is expected at the Illicit PCB Dump Site given the removal action, the installation and current condition of the cap, and the absence of contamination in groundwater. Recommendations regarding 1) abandonment of those wells installed at this site during the 1980 s to prevent them from being a potential route for contaminant migration and 2) installation of a 6-ft-high chain link fence around the site to prevent any disturbance of the site, have been completed. Debrushing of the cap has also been performed. Additional groundwater sampling over a two-year period is underway with two rounds completed. Two more rounds of groundwater sampling should be completed, with one round in the winter and one in the spring. The samples should be analyzed for PCBs and triclorobenzene. If no contamination is detected, it is recommended that the site be closed. Further investigation may be necessary if contamination is detected. In either case, this site should be included as part of the future Institutional Control Plan for Fort Lewis and the Logistics Center 5-year reviews because contamination is being left in place. These recommendations should also be addressed in the ESD to the Logistics Center ROD.

Blood lead level contributions resulting from exposure to residual lead at the Battery Acid Pit were found to be five times below the EPA guideline of $10 \mu \mathrm{g} \mathrm{Pb} / \mathrm{dL}$ blood. Estimated values for the individual pathways were: 1) inhalation 9.9E-4 $\mu \mathrm{g} \mathrm{Pb} / \mathrm{dL}$ blood, 2) ingestion $0.71 \mu \mathrm{g}$ $\mathrm{Pb} / \mathrm{dL}$ blood, and 3) dermal contact $0.40 \mu \mathrm{g} \mathrm{Pb} / \mathrm{dL}$ blood. The total potential median blood level was calculated to be $1.1 \mu \mathrm{g} \mathrm{Pb} / \mathrm{dL}$ blood. At the 95th percentile, the blood level concentration was determined to be $2.0 \mu \mathrm{g} \mathrm{Pb} / \mathrm{dL}$ blood. Additionally, a blood lead level of $1.3 \mathrm{E}-15 \mu \mathrm{g} \mathrm{Pb} / \mathrm{dL}$ blood was calculated from the MEPAS code for an individual located $100 \mathrm{~m}$ from the site. This value is also significantly below the EPA guideline. As a result, no further action, other than paving the site with asphalt (now completed) to remove any exposure potential altogether, is recommended for the Battery Acid Pit. EPA should be notified and the health impact assessment updated if the land use changes to residential. The site should also be included in the Fort Lewis Logistics Center 5-year reviews because contamination is being left in place. Additionally, these recommendations should be addressed in the ESD to the Logistics Center ROD. 


\subsection{References}

ARS Agriculture Research Service Pesticide Properties Database http://www.arsusda.gov/rsml/ppdb2.html

Bell, R.M., 1992. Higher Plan Accumulation of Organic Pollutants from Soils. EPA/600/R92/138, U.S. Environmental Protection Agency, Cincinnati, Ohio.

Boggess, W.R. (ed.), 1977. Lead in the Environment. NSF/RA-770214, U.S. Government Printing Office, Washington, D.C.

Cal EPA, 1996. Supplemental Guidance for Human Health Multimedia Risk Assessments of Hazardous Waste Sites and Permitted Facilities. Department of Toxic Substances Control, Environmental Protection Agency, State of California.

Carlisle, J. C. and M. J. Wade, 1992. "Predicting blood lead concentrations from environmental concentrations.” Reg. Toxicol. Pharmacol. 16:280-289.

Chaney, R.L., H. W. Mielke, and S. B. Sterrett, 1990. Speciation, Mobility, and Bioavailability of Soil Lead. Environ. Geochem. and Health.

Cowherd, C. Jr., G. E. Muleski, P. J. Englehart, and D. A. Gillette, 1984. Rapid assessment of exposure to particulate emissions from surface contamination sites. Kansas City, Missouri.

Midwest Research Institute.

Droppo, J. G., Jr. and J. W. Buck, 1996. Multimedia Environmental Pollutant Assessment System (MEPAS): Atmospheric Pathway Formulation. PNL-11080. Pacific Northwest National Laboratory, Richland, Washington.

Ecology, 1997. Interim Interpretive and Policy Statement, Cleanup of Total Petroleum Hydrocarbons (TPH). Ecology Publication No. ECY97-600, January 1997.

EPA, 1996. Soil Screening Guidance: Technical Background Document. EPA/540/R95/128. Office of Solid Waste and Emergency Response. Washington, D.C.

EPA, 1998. Preliminary Remediation Goals, Updated June 3, 1998 http://www.epa.gov/region09/waste/sfund/prg/index.html 
Hong West \& Associates, 1993. Port of Seattle Street Sweeping Disposal Site Environmental Assessment. Seattle, Washington.

McBride M. B., 1994. Environmental Chemistry of Soil. Oxford University Press, New York.

McDougall, 1949. Plant Ecology. Lea and Febiger, Philadelphia, Pennsylvania.

OSWER, 1998. Interim Soil Lead Guidance for CERCLA Sites and RCRA Corrective Facilities. Office of Solid Waste and Emergency Response Directive No. 9200.4-27P, August 27, 1998.

Public Works, 1998. Installation Restoration Action Plan for Fort Lewis and Subinstallations Yakima Training Center, Vancouver Barracks, USASC SATCOM (Camp Roberts), Environmental and Natural Resources Division, Public Works, Fort Lewis, Washington.

Serdar, D., 1993. Contaminants in Vactor Truck Wastes. Washington State Department of Ecology. Olympia, Washington.

Streile, G. P., K. D. Shields, J. L. Stroh, L. M. Bagaasen, G. Whelan, J. P. McDonald, J. G. Droppo, and J. W. Buck, 1996. Multimedia Environmental Pollutant Assessment System (MEPAS): Source Term Formulation. PNL-11248. Pacific Northwest National Laboratory, Richland, Washington.

Tetra Tech, 1993. Final Management Plan for Hazardous Waste Sites. Fort Lewis Military Reservation, Fort Lewis, Washington.

U.S. Army, 1990. Hazardous Waste Evaluation Report for Fort Lewis, Washington.

Environmental and Natural Resources Division, Directorate of Engineering and Housing, I Corps and Fort Lewis, AFZH-DEQ. Fort Lewis, Washington.

WAC 173-160. Minimum Standards for Construction and Maintenance of Wells. State of Washington Department of Ecology.

Whelan, G., J.W. Buck, D.L. Strenge, J.G. Droppo, Jr., and B.L. Hoopes, 1992. Overview of the Multimedia Environmental Pollutant Assessment System (MEPAS). Hazardous Waste \& Hazardous Materials, Volume 9, Number 2.

Woodward-Clyde, 1993. Final Technical Memorandum, Fort Lewis Logistics Center Limited Field Investigation: Confirmational Soil Sampling, Fort Lewis, Washington. 
Woodward-Clyde, 1994. Limited Field Investigation Report, Multi-Site Limited Field Investigation, Fort Lewis, Washington.

Woodward-Clyde, 1995. Fort Lewis Logistics Center Limited Field Investigation Confirmational Soil Sampling, Fort Lewis, Washington.

Woodward-Clyde, 1998. Fort Lewis Logistics Center Remedial Action Monitoring. Second Year Monitoring Report. U.S. Army Corps of Engineers, Seattle, Washington. 